\title{
Double batch cider distillation: influence of the recycling of the separated fractions.
} Guichard $^{\text {de }}$

Martine Esteban-Decloux ${ }^{a, *}$, Jean-Christophe Dechatre ${ }^{b}$, Patrick Legendre ${ }^{c}$, Hugues

${ }^{a}$ UMR 782 SayFood, AgroParisTech-INRAE, Paris-Saclay University, 1 avenue des Olympiades F-91300 MASSY, France

${ }^{b}$ ARAC (Association for Cider Processing Applied Research), Lycée Robillard F-14700 LIEURY, France

${ }^{c}$ LABEO, 1 route de Rosel, Saint Contest F-14053 CAEN, France

${ }^{\mathrm{d}}$ IFPC (French Institute for Cider Production), Domaine de la Motte, F-35653 LE RHEU, France

e UMT Nova²cidre, Domaine de la Motte, F-35653 LE RHEU, France

* Correspondence to: Martine ESTEBAN-DECLOUX

UMR 782 SayFood - AgroParisTech- 1, av des Olympiades, F-91300 Massy, France

E-mail: martine.decloux@agroparistech.fr

Tel: +33634415800

\begin{abstract}
This study aimed to analyse the behaviour of volatile compounds during double batch cider distillation to produce Calvados. More precisely, it allowed to analyse the influence of the recycling of the separated fractions to manage the cuts according to the quality target. $700 \mathrm{~L}$ of cider were distilled with a $115 \mathrm{~L}$ Charentais still and 28 congeners were quantified into 65 samples from nine cider and two brouillis distillations. Most of alcohols were totally recovered into the heart of the second brouillis distillation, except 2-phenylethanol recovered at $5.4 \%$ because of its low volatility. For the same reason, esters as 2-phenylacetate, ethyl 2hydroxypropanoate and diethyl butanedioate were significantly lost in the residues. Stopping distillations beyond $2 \% \mathrm{v} / \mathrm{v}$ would increase their recovery but at an increasing cost. Other compounds are strongly concentrated in the head fractions. Among them, some such as ethyl acetate and acetaldehyde have negative impact on quality, while others such as ethyl decanoate and ethyl hexanoate bring floral notes. As these positive compounds are less concentrated in the head fraction of brouillis distillation than cider distillation, it is best, if negative compounds must be eliminated, to choose to extract head from brouillis distillation. Other possibility is to limit production of negative compounds.
\end{abstract}

Abbreviation list:

$\begin{array}{lll}\text { AOC } & : & \text { Appellation d'Origine Contrôlée } \\ \text { ABV } & : & \text { Alcohol By Volume }(\% \mathrm{v} / \mathrm{v}) \\ \text { B } & : & \text { Brouillis } \\ \text { BD } & : & \text { Brouillis Distillation } \\ \text { CD } & : & \text { Cider Distillation } \\ \text { Dv } & : & \text { Dead volume } \\ \text { Hd } & : & \text { Head } \\ \text { hL PA } & : & \text { hectolitre of Pure Alcohol } \\ \text { Ht } & : & \text { Heart }\end{array}$




\begin{tabular}{lll} 
OAV & $:$ & Odorant Active Value \\
R & $:$ & Residue \\
S: & \multicolumn{2}{l}{ Second } \\
T & $: \quad$ Tail
\end{tabular}

\section{Introduction}

Calvados is a brandy produced in Normandy, north-west of France, from ciders obtained with particular varieties of apples and pears. Today, there are three Calvados appellations (AOC). Each one has unique and distinct characteristics, based on the geographical area of production and distillation processes referenced in decrees $n^{\circ} 2015-133,2015-134$ and 201512, concerning respectively Calvados, Calvados Pays d'Auge and Calvados Domfrontais. Thus, the fruits are scrupulously selected for cider preparation which has to follow specific rules. Cider must contain an ethanol content higher than $4.5 \% \mathrm{v} / \mathrm{v}$ ABV (Alcohol By Volume unit). Calvados Pays d'Auge must be produced by double batch distillation with many recycling, using a discontinuous copper still with a boiler capacity smaller than $25 \mathrm{hL}$ (Fig. 1). During cider distillation $(\mathrm{CD})$, three distillate fractions are successively collected: the head $\left(\mathrm{Hd}_{\mathrm{CD}}\right)$ from 50 to $42 \% \mathrm{v} / \mathrm{v}$, the brouillis (B) from 42 to $13-15 \% \mathrm{v} / \mathrm{v}$ and the tail $\left(\mathrm{T}_{\mathrm{CD}}\right)$ collected until 2$3 \% \mathrm{v} / \mathrm{v}$. $\mathrm{Hd}_{\mathrm{CD}}$ and $\mathrm{T}_{\mathrm{CD}}$ are recycled into the cider for the next distillation. At least four distillations of cider with recycling of fractions of head and tail, are necessary to have enough distillate for the second distillation. During this distillation also called brouillis distillation (BD), four fractions of distillate are collected successively: the head $\left(\mathrm{Hd}_{\mathrm{BD}}\right)$ from 85 to $80 \% \mathrm{v} / \mathrm{v}$, the heart $(\mathrm{Ht})$ until $60 \% \mathrm{v} / \mathrm{v}$, the second $\left(\mathrm{S}_{\mathrm{BD}}\right)$ from 60 to $15 \% \mathrm{v} / \mathrm{v}$ and the tail $\left(\mathrm{T}_{\mathrm{BD}}\right)$ from 15 to $2-3 \% \mathrm{v} / \mathrm{v} . \mathrm{S}_{\mathrm{BD}}$ is recycled into the brouillis of the next brouillis distillation (BD) and $\mathrm{Hd}_{\mathrm{BD}}$ and $\mathrm{T}_{\mathrm{BD}}$ are recycled into the cider. The alcohol concentration of the heart $(\mathrm{Ht})$ must not be higher than $72 \% \mathrm{v} / \mathrm{v}$ and the concentration of congeners compounds before aging (methanol excepted) must be higher than $325 \mathrm{~g} / \mathrm{hL}$ PA (gram per hectolitre of Pure Alcohol) for the Calvados and $350 \mathrm{~g} / \mathrm{hL}$ PA for the Calvados Pays d'Auge and Calvados Domfrontais. Methanol concentration should not exceed $200 \mathrm{~g} / \mathrm{hL}$ PA. Methanol is a major concern in these brandies due to the methylated pectins in the fruit that become demethylated on ripening and mainly when juices are clarified with pectinase. In some cases, depending on the cider composition to be distilled, a small part of the head fractions from cider and brouillis distillations can be definitively eliminated.

Aroma of Calvados has already been studied by several authors (Guichard et al., 2003, Ledauphin et al., 2003), who highlighted the presence of identical molecules in different samples, defining a specific aroma skeleton. Importance of 2-phenylethanol and its corresponding acetate were mentioned for floral characteristics as well as ethyl 2methylpropanoate, ethyl 2-methylbutanoate and 3-methylbutyl acetate for the fruity notes. The distillate composition is influenced by the distillation technique, double batch distillation giving the highest concentration of ethyl acetate. On the contrary, the long-chain alcohols are better recovered with the continuous rectification (Madrera et al., 2003a). On the other hand, these authors mentioned that the acetate esters degradation during aging is lower in distillates obtained by double batch distillation. This type of distillation is also susceptible to give higher concentration of volatile furanic compounds, such as 5-methylfurfural, furfural, and 2furylmethyl ketone (Madrera et al., 2003b). The distillate composition is also influenced by the raw material, those made out with traditional method having higher concentration in long-chain fatty acids and long-chain ethyl esters (Mangas et al., 1996b). Distillates made with apple juice concentrate have higher methanol concentration, possibly due to enzymatic treatment used for 
apple juice concentrate manufacturing (Mangas et al., 1996a). Furthermore, distillation of cider made out of concentrate leads to higher furfural concentration (Mangas et al., 1996c). Two compounds, 1-butanol and ethyl hexanoate, were cited as key compounds to discriminate distillates based on their raw material (Madrera \& Mangas, 2005). Using the same distillation method, it has been shown that ethyl octanoate, hexyl 2-methylbutyrate, hexan-1-ol, benzaldehyde and furfural reach different concentration depending on apple variety used from cider manufacturing (Versini et al., 2009).

In 2015, a change in the regulation of the AOC of Calvados occurred, authorizing amongst other, yeast inoculation for fermentation (decrees $\mathrm{n}^{\circ} 2015-133$ and 2015-134). A specific project has been designed in order to help producers to master those new rules and to answer the industry needs for new products with more fruity and floral characteristics. The present study is part of this project as it is important to consider the distillation influence on the behaviour of compounds responsible for fruity and floral notes, such as acetate esters, in particular pentyl, 3-methylbutyl, hexyl and 2-phenylethyl acetates (Guichard et al., 2019).

Most of the studies on volatile compounds behaviour during batch distillation have been carried out on a single distillation without considering the numerous recycling (Zhao et al., 2014; Douady et al., 2019; Xiang et al., 2020). However, as shown in Fig. 1, it is important for double batch distillation to study all these recycling in order to have a better understanding of the role of distillation on the heart composition. This is the purpose of the present study. It was decided (i) to take into account the many recycling processes, (ii) to study a cider called «piqué» (volatile acidity around $2 \mathrm{~g} \mathrm{H}_{2} \mathrm{SO}_{4} / \mathrm{L}$ ) to make a point about the impact of negative compounds recycled at high concentration, for instance ethyl acetate being directly linked to this defect at high concentration, (iii) to take average samples and analyse their volatile composition, (iv) to estimate the mass or volume of each fraction collected during distillation, (v) and to measure the ethanol content over time.

\section{Materials and Methods}

\subsection{Distillation methods}

All distillations were carried out in a pilot plant with a $115 \mathrm{~L}$ copper still (Groupe Chalvignac 17520 Jarnac, France) heated with electrical resistances (Fig. 2). The still was equipped with six temperature probes (TC S.A, Dardilly, France), a balance $(0-25 \mathrm{~kg} \pm 0.05 \mathrm{~kg})$, electrical resistances $(3 * 4800 \mathrm{~W})$, a cold-water supply regulated by opening a needle valve depending on the water outlet temperature and a LABVIEW National Instrument data acquisition system (Austin, US) with a recording every 30 seconds of temperatures, distillate mass and heating power. Ethanol content (ABV) was measured using a densimeter DMA 35 (Anton Paar, Les Ulis, France), for distillate samples over time during four distillations. For cider and residue samples, ABV were measured using a boiling meter (Dujardin Salleron, Noizay, France). All the collected samples were kept before analysis into sealed bottle at $-20{ }^{\circ} \mathrm{C}$ for cider and residue samples and at $4^{\circ} \mathrm{C}$ for the other samples. Masses of each fraction and samples were also measured precisely.

Organization of the cider and brouillis distillation experiments is detailed Fig. 3.

\subsubsection{Cider Distillations}

For the first distillation (CD1), the cider was introduced alone into the boiler. For CD2 to $\mathrm{CD} 5$, head and tail of each previous cider distillation $\left(\mathrm{Hd}_{\mathrm{CDn}-1}+\mathrm{T}_{\mathrm{CDn}-1}\right)$ were recycled into the 
next cider distillation. For CD6 to CD9, head and tail of the previous cider distillation, plus a

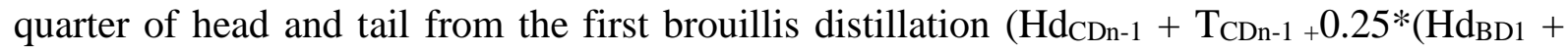
$\left.\mathrm{T}_{\mathrm{BD} 1}\right)$ ) were added to the cider to be distilled. After agitation and sampling of those mixtures, around $92 \mathrm{~kg}$ of solution were weighed and introduced into the boiler for distillation.

The cider distillations were conducted as follows: after data acquisition start, the heating power was set at $100 \%$ and reduced to $35 \%$ as soon as the swan neck temperature reached $55^{\circ} \mathrm{C}$. The distillate temperature was maintained between 11 and $14^{\circ} \mathrm{C}$. Regarding the head, the first $0.2 \mathrm{~L}$ were eliminated and the $1.4 \mathrm{~L}$ remaining were sampled before their recycling into the next cider distillation. The brouillis was then collected up to a $13 \% \mathrm{v} / \mathrm{v}$ and sampled after mixing $\left(\mathrm{B}_{\mathrm{CDn}}\right)$. The distillate tank was changed and the power increased to $50 \%$ to collect the tail up to $2 \% \mathrm{v} / \mathrm{v}$. Tail was sampled. Head and tail were mixed before their recycling into the cider for the next distillation. Heat was shut down and once the system was completely cold, the residue $\left(\mathrm{R}_{\mathrm{CDn}}\right)$ was recovered and sampled. The coil and the alcoholmeter were then emptied to collect the dead volume $\left(\mathrm{Dv}_{\mathrm{CDn}}\right)$. This volume was measured and sampled. The objective was to quantify the loss of compounds in this generally neglected fraction.

\subsubsection{Brouillis distillations}

For the first brouillis distillation (BD1), the brouillis obtained from cider distillations (CD1 to CD5) were mixed and approximately $80 \mathrm{~kg}$ were introduced into the boiler. For the second brouillis distillation (BD2), the brouillis obtained during the cider distillations CD6 to $\mathrm{CD} 9$ were mixed with the fraction of second from BD1 $\left(\mathrm{S}_{\mathrm{BD} 1}\right)$.

The brouillis distillations were operated as follows: after data acquisition start, the heating power was set at $100 \%$ then reduced to $35 \%$ when the sawn neck temperature reached $55^{\circ} \mathrm{C}$. The first $0.2 \mathrm{~L}$ of head fraction were discarded and the next $1.4 \mathrm{~L}$ were collected, sampled $\left(\mathrm{Hd}_{\mathrm{BDn}}\right)$ and kept for their distribution into the four next cider distillations. The heart was then collected up to $60 \% \mathrm{v} / \mathrm{v}$. The heart was mixed and sampled $\left(\mathrm{Ht}_{\mathrm{BDn}}\right)$. The distillate tank was changed and the power increased to $50 \%$. The fraction of second $\left(\mathrm{S}_{\mathrm{BDn}}\right)$ was collected up to $13 \% \mathrm{v} / \mathrm{v}$. After mixing, this fraction was sampled $\left(\mathrm{S}_{\mathrm{BDn}}\right)$ and kept. The distillate tank was changed again and the power increased to $70 \%$ to collect the tail up to $2 \% \mathrm{v} / \mathrm{v}$. After its mixing and sampling $\left(\mathrm{T}_{\mathrm{BDn}}\right)$, the tail was kept for recycling into the four next cider distillations. As previously, the power was shut down, and then the residue $\left(\mathrm{R}_{\mathrm{BDn}}\right)$ and the dead volume $\left(\mathrm{Dv}_{\mathrm{BCn}}\right)$ were collected.

\subsection{Sample analysis}

Sixty-six compounds were analysed on the 65 average samples from the nine cider distillations and the two brouillis distillations, corresponding to 16 alcohols, 37 esters, 7 aldehydes and 6 phenols (Table 1).

Three analysis methods were used depending on compounds as following:

Method A: GC-FID analysis with direct injection, or after laboratory distillation for ciders and cider residues, according to the commission regulation (EC) No 2870/2000 (Official Journal of the European Communities, 2000). The laboratory distillation was conducted on a $100 \mathrm{~mL}$ test sample according to the OIV-MA-BS-02 method for spirit beverages (OIV, 2014). For dead-volume and residue samples, $7 \mathrm{~mL}$ of absolute ethanol were added to achieve an ethanol concentration similar to cider. The GC-FID analyses were carried out on a 7890B GC System (Agilent Technologies) coupled with a split injector and a flame ionization detector. 
Separation was performed using CPWAX57 CB capillary column $(50 \mathrm{~m}$ x $0.25 \mathrm{~mm}, 0.20 \mu \mathrm{m}$ film thickness, Agilent Technologies) and nitrogen as carrier gas at a constant flow of $1.0 \mathrm{~mL} / \mathrm{min}$. The injector was heated at $220^{\circ} \mathrm{C}$ with a split value of $25: 1$. The $\mathrm{GC}$ oven was programmed as follow: initial temperature at $35{ }^{\circ} \mathrm{C}$ for $5 \mathrm{~min}$, raised at $3{ }^{\circ} \mathrm{C} / \mathrm{min}$ to $110{ }^{\circ} \mathrm{C}$ maintained for $2 \mathrm{~min}$ then $15{ }^{\circ} \mathrm{C} / \mathrm{min}$ to $200{ }^{\circ} \mathrm{C}$ maintained for $12 \mathrm{~min}$. Detector was heated at $250{ }^{\circ} \mathrm{C}$. Compounds identification was carried out using commercial standards retention times. Quantification was performed using linear calibration curves with an internal standard (2methyl-4-pentanol) added before injection.

Method B: GC-MS analysis after liquid/liquid extraction of the distilled fractions obtained with the still or after laboratory distillation for ciders and cider residues, using a dichloromethane/pentane $(1 / 2 \mathrm{v} / \mathrm{v})$ mix. Before extraction, the alcoholic concentration was adjusted to $7 \% \mathrm{v} / \mathrm{v}$ for $90 \mathrm{~mL}$ final volume. $5 \mathrm{~g}$ of sodium chloride and $100 \mu \mathrm{L}$ of internal standard solution containing methyl undecanoate $0.015 \% \mathrm{v} / \mathrm{v}$ (Sigma) and 2-methyl-4-pentanol $0.15 \% \mathrm{v} / \mathrm{v}$ (Aldrich) were added to samples. The liquid extractions were performed twice with $4 \mathrm{~mL}$ of extraction solvent. The extracts were kept at $-25{ }^{\circ} \mathrm{C}$ during one hour to remove water content. Supernatant were concentrated under a gentle stream of nitrogen to a $500 \mu \mathrm{L}$ volume. GC-MS analyses were carried out on an HP 6890 GC System (Agilent Technologies) coupled with a split injector and a mass detector HP 5973. Separation was performed using Rxi_XLB capillary column ( $30 \mathrm{~m} \times 0.25 \mathrm{~mm}$, film thickness $0.25 \mu \mathrm{m}$, Restek) and helium as carrier gas at a constant flow of $1.0 \mathrm{~mL} / \mathrm{min}$. The injector was heated at $280{ }^{\circ} \mathrm{C}$ with a split value of 20:1. The GC oven was programmed as follow: initial temperature at $40{ }^{\circ} \mathrm{C}$ for $5 \mathrm{~min}$, raised at $10{ }^{\circ} \mathrm{C} / \mathrm{min}$ to $300{ }^{\circ} \mathrm{C}$ maintained for $5 \mathrm{~min}$. Mass spectrometer operated in electron ionisation (EI) at $70 \mathrm{eV}$ with ion source temperature at $280{ }^{\circ} \mathrm{C}$ and quadrupole temperature at $150{ }^{\circ} \mathrm{C}$. For quantification, mass spectra were acquired in Selected Ion Monitoring (SIM) mode. Identification and quantification of volatile compounds were carried out using commercial standards. Calibration was performed after extraction of standard range synthetic solutions containing higher alcohols to simulate a brandy and spiked with each commercial standard.

Method C: direct injection on HPLC UV-DAD for analyses of volatile phenols. These analyses were carried out using Agilent 1100 HPLC system equipped with UV-DAD. Prior to analysis the samples were filtered through $0,45 \mu \mathrm{m}$ PVDF filter (Millipore) and diluted two or four times according to the alcoholic content. $50 \mu \mathrm{L}$ were injected into a RAPTOR ARC-18 column $\left(5 \mu \mathrm{m}, 100 \times 3.0 \mathrm{~mm}\right.$, Restek) kept at $40{ }^{\circ} \mathrm{C}$. The separation was performed by a gradient elution using two mobile phases, a water/acetonitrile solution acidified with $0.1 \%$ phosphoric acid, mixed with acidified acetonitrile in proportion going from $20 \%$ to $90 \%$, at the flow rate of $0.4 \mathrm{~mL} / \mathrm{min}$. The acidified acetonitrile gradient was programmed as follow: $30 \%$ at $4.25 \mathrm{~min}, 50 \%$ at $8.5 \mathrm{~min}$ and $90 \%$ at $12.75 \mathrm{~min}$ maintained for $2.25 \mathrm{~min}$. Compounds identification were based on the retention time for each peak and their UV spectra in comparison with those of 4-Ethyl catechol (Alfa Aesar), 4-Ethylphenol, 4-Ethylguaiacol, 4-Vinylphenol, 4Vinylgaiacol (Sigma-Aldrich) standards. Quantification was performed using the calibration curves ranging from 0.05 to $5.00 \mathrm{mg} / \mathrm{L}$.

Details on the limit range of quantification is developed in Table 1.

\section{Results}

Nine cider distillations were conducted according to the procedure described in part 2. All details concerning each fraction i.e., weight, ABV and distillation duration are shown in Table 2. For all cider distillations with head and tail fractions recycling (CD2 to CD9), mean 
values and standard deviations for the different distillate fractions collected were calculated. Small standard deviations and good reproducibility of the parameters can be observed.

Two brouillis distillations were carried out to consider the second fraction $\left(\mathrm{S}_{\mathrm{BD} 1}\right)$ recycling, coming from the first brouillis distillation, into the second distillation. Data of the brouillis distillations are reported in Table 3. In that case no means and standard deviations were calculated as the number of performed distillations was not sufficient.

The mass and alcohol balances allowed to account for the ethanol part coming from the different recycling: for the cider distillations 6 to $9,8.2 \%$ for $\mathrm{H}_{\mathrm{CDn}-1}, 9.0 \%$ for $\mathrm{T}_{\mathrm{CDn}-1}$ and $3.5 \%$ for $0.25 *\left(\mathrm{H}_{\mathrm{BD} 1}+\mathrm{T}_{\mathrm{BD} 1}\right)$ respectively for a total of $20.7 \%$ and for the brouillis distillation $\mathrm{BD} 2$, the recycling of the second fraction $\left(\mathrm{S}_{\mathrm{BD} 1}\right)$ provides $19.4 \%$ of the ethanol.

For cider distillations, examples of evolution over time are given in Fig. 4 for the following parameters: heating power, distillate mass, temperatures (boiler, head, gooseneck's top and the gooseneck's bottom), and ethanol mass concentration of the distillate taken every five minutes. In the same way, the parameters were followed over the time during the brouillis distillations. An example is given in Fig. 5.

Among the 66 volatile compounds analysed with the methods described above (Table 1) 28 compounds (12 alcohols, 9 esters, 3 aldehydes and 4 phenols) were at sufficient concentrations to be quantified (above their limit of quantification). The mass of each compound in each fraction was calculated. The mass into the boiler was compared to the sum of the masses of each fraction according to Eq. 1 for cider distillations and Eq. 2 for brouillis distillations.

$$
\begin{aligned}
& \text { Balance (\%) of } i \text { for } C D=\frac{\left(m_{i}^{H d}+m_{i}^{B}+m_{i}^{T}+m_{i}^{D v}+m_{i}^{R}\right)-\left(m_{i}^{\text {boiler }}\right)}{m_{i}^{\text {biller }}} * 100 \\
& \text { Balance (\%) of } i \text { for } B D=\frac{\left(m_{i}^{H d}+m_{i}^{H t}+m_{i}^{S}+m_{i}^{T}+m_{i}^{D v}+m_{i}^{R}\right)-\left(m_{i}^{\text {boiler }}\right)}{m_{i}^{\text {boiler }}} * 100
\end{aligned}
$$

With, $m_{i}^{x}$ the mass of compound $i$ into the fraction $x$ (boiler, head, brouillis, heart, second, tail, dead volume, residue).

A positive balance value indicates that the mass accounted for the outputs is higher than the mass of the inputs. A negative value indicates the opposite. The differences in balance may be due to several factors: (i) analytical difficulties especially for boiler and residue solutions quantification, (ii) compounds formation as shown by Awad et al. (2017) in the case of cognac wine distillation in absence of lees, (iii) reactivity of some compounds.

\subsection{Distribution of volatile compounds during cider distillations}

For the cider distillations 2 to 9, compounds mean concentrations, as well as their standard deviations and estimated mass balance, are displayed on Table 4. The standard deviations are globally low. Two explanations can be raised: (i) only concentrations from cider distillations 2 , with the recycling of the head and tail fractions from the previous cider distillation, were considered, (ii) from cider distillation 6, fractions recycled from the brouillis distillation represent a very small addition (1.5\% of the mass and $3.5 \%$ of the ethanol).

For most alcohols quantified, the mass balance is coherent, except for (Z)-hex-3-en-1-ol and pentan-1-ol as very positive balances of respectively $68 \%$ and $41 \%$ were obtained. This may be explained by their very low concentrations into the boiler. As for others fermented 
products, alcohols are the most concentrated volatile compounds, particularly the 3methylbutan-1-ol. However, propan-1-ol and butan-2-ol have unusual high concentrations (270.1 mg/L and $71.5 \mathrm{mg} / \mathrm{L}$ respectively) which is due to the choice of a "piqué" cider with high acidity. Generally, propan-1-ol concentration is of the same order of magnitude as 2methylpropan-1-ol, and butan-2-ol is at very low concentration. The high butan-2-ol concentration allowed us to study its behaviour, which is rarely mentioned in the literature. Butan-2-ol is highly concentrated in head fractions since the concentration is higher than $1300 \mathrm{mg} / \mathrm{L}$. Methanol concentration of $56 \mathrm{mg} / \mathrm{L}(78 \mathrm{~g} / \mathrm{hL} \mathrm{PA})$, is largely lower than the regulatory maximum limit of $200 \mathrm{~g} / \mathrm{hL} \mathrm{PA}$. Most of the alcohols analysed are highly concentrated in head fraction and then their concentration decreases as distillation progresses. On the contrary, 2-phenylethanol concentration increases from head to brouillis and then tail. Its concentration is also significant in the residue. This behaviour is consistent with the results presented by Douady et al. (2019) and the equilibrium liquid/vapour data listed by Puentes et al. (2018). Thus, part of this floral compounds is definitely lost into the residue.

Regarding the esters quantified, the mass balance is not consistent for ethyl octanoate, 2phenylethyl acetate and ethyl 3-hydroxybutanoate with mass differences higher then $\pm 25 \%$. Again, very low concentrations in the cider may justify these inconsistencies. The highest concentrated esters in the boiler are ethyl acetate and ethyl 2-hydroxypropanoate with more than $220 \mathrm{mg} / \mathrm{L}$ followed by ethyl propanoate $(15.6 \mathrm{mg} / \mathrm{L})$, diethyl butanedioate $(6.3 \mathrm{mg} / \mathrm{L})$, ethyl octanoate $(2.9 \mathrm{mg} / \mathrm{L}), 3$-methylbutyl acetate $(1.2 \mathrm{mg} / \mathrm{L})$ and ethyl decanoate $(0.4 \mathrm{mg} / \mathrm{L})$. All other esters are found at concentrations below $0.4 \mathrm{mg} / \mathrm{L}$ and even at concentrations lower than their limit of quantification. For esters with correct mass balance, except ethyl 2hydroxypropanoate and diethyl butanedioate, the concentrations are higher in the head fraction, then decrease, which is consistent with the literature (Puentes et al., 2018; Douady et al., 2019). On the contrary, ethyl 2-hydroxypropanoate and diethyl butanedioate have an equivalent behaviour to 2-phenylethanol with a concentration increase as distillation progresses and a still significant concentration in the residue. Therefore, a fraction of these compounds is definitively lost.

For aldehydes, mass balances show that estimated masses in the distillate fractions are at least the double of those estimated into the boiler. This may be due to reactions with the precursors present in the cider as was shown by Awad et al. (2017) during the distillation of the wine to produce cognac. Acetaldehyde, 1,1-diethoxyethane and 2-methylpropanal are highly concentrated in the head fraction.

Regarding analysed phenols in cider, 4-ethylcatechol is significantly more concentrated $(19.6 \mathrm{mg} / \mathrm{L})$ than 4-ethylphenol $(3.4 \mathrm{mg} / \mathrm{L})$ and 4-ethylguaiacol $(0.7 \mathrm{mg} / \mathrm{L})$. This result is in agreement with previous results (Buron et al., 2011). However, these compounds are related with defect in cider (Buron et al., 2011 and 2012) and their impact in Calvados is questionable. The obtained data do not allow us to define a homogeneous behaviour: 4-ethylcatechol is concentrated in head and residue fractions but not in the brouillis which is not consistent; 4ethylphenol concentration increases from head to tail and then decreases sharply which would indicate relatively low volatility compared to ethanol; 4-ethylguaiacol follows nearly the same behaviour as the previous compounds but with lower concentrations; finally, 4-vinylanisol concentration is too low to correctly estimate its behaviour.

To get an idea of the concentration of the volatile compounds compared to ethanol, it is also possible to calculate the compounds concentration in $\mathrm{g} / \mathrm{hL}$ PA. For cider distillations 1 to 
9, the variation of brouillis composition for highly concentrated compounds are showed in Fig. 6. From the sixth distillation with the recycling of $25 \%$ of head and tail fractions from the brouillis distillation, a steady concentration is practically reached. This is consistent with the low standard deviations observed above (Table 4) and the small proportion represented by the recycled fraction from the brouillis distillation.

\subsection{Distribution of volatile compounds during brouillis distillations}

The compounds concentration in the fractions of both brouillis distillations (boiler, head, heart, second, tail, dead-volume and residue) are reported in Table 5. In the first brouillis distillation (BD1), there was no second fraction recycling as explained previously. Similarly, to cider distillations, mass balances are very coherent for alcohols but attention must be paid in the case of esters for which there are many discrepancies (3-methylbutyl acetate, ethyl decanoate, 2-phenylethyl acetate, ethyl 3-hydroxybutanoate and ethyl propionate) as well as for 1,1-diethoxyethane.

For highly concentrated compounds, concentrations expressed in $\mathrm{g} / \mathrm{hL}$ PA are presented in Fig. 7. Most of the compounds are less concentrated in the heart of the second distillation $\left(\mathrm{Ht}_{\mathrm{BD}}\right)$ than in the first one. Compounds with increasing concentrations in $\mathrm{Ht}_{\mathrm{BD} 2}$ are those with significant concentrations in the seconds' fractions, in particular 2-phenylethanol, ethyl 2hydroxypropanoate, diethyl butanedioate and 4-ethylguaiacol. This can be explained by their increasing concentrations with ethanol concentration decrease into the boiler. This behaviour is consistent with the classification of (Douady et al., 2019) in type 6 (increase concentration with decrease ethanol concentration) and Xiang et al. (2020) in cluster 3 and 9 (overall upward trend). The seconds' fraction recycling may explain their concentration increase in heart. However, unlike cider distillations, it is not certain that the steady state was achieved because it was not possible to perform a third or even a fourth brouillis distillation due to the necessary number of cider distillations to produce enough brouillis.

\section{Discussion}

For quantified compounds, repartition into the different fractions were calculated on the basis of recovered total mass into distillate fractions and residue for cider distillations (Table 6) and second brouillis distillation (Table 7). Compounds with mass balance difference higher than $\pm 25 \%$ are indicated in italics.

As can be seen, the majority of analysed alcohols are found either in brouillis, heart or recycled fractions, except 2-phenylethanol, which remains at each distillation into eliminated fractions (dead volume and residue) for more than 47\%. The other alcohols are mainly distributed in the head fraction of cider distillation and the heart fraction of brouillis distillation. Thus, if their concentration in the final heart must be reduced, it is necessary to eliminate part of the head fraction of cider distillation. Contrary to what is often thought, methanol does not particularly concentrate in heads and even more, a small fraction remains in the residue. Butan2-ol has nearly the same repartition than butan-1-ol and hexan-1-ol.

Ethyl acetate is highly concentrated in heads. However, other interesting esters for quality properties such as 3-methylbutyl acetate and ethyl decanoate, also concentrate in this fraction. This underlines the difficulty to decide whether or not to eliminate part of head fractions. Since 3-methylbutyl acetate and ethyl decanoate are significantly less concentrated in head fraction of the brouillis distillation (Table 7) than in head fraction of the cider distillation (Table 6), there may be an advantage of eliminating part of head fraction of brouillis distillation to remove 
negative compounds such as ethyl acetate while minimizing the loss of the interesting esters.

The results for 4-ethylcatechol show a contradictory behaviour as the remaining part in the residue is estimated to $98.8 \%$ during cider distillation (Table 6) compared to $15.9 \%$ during brouillis distillation (Table 7). This might be explained by possible interactions with polyphenols in cider resulting in its retention in the residue. Indeed, polyphenols are precursors of 4-ethylcatechol (Buron et al., 2011) and both molecules contain the phenyl cycle with hydroxyl group that might react together to form bonds. Polyphenols are not present in brouillis which explains the low proportion remaining in the residue for brouillis distillation. The high polarity of 4-ethylcatechol might explain as well this behaviour during cider distillation. As a consequence, even a concentration as high as the one found in the present cider $(19.6 \mathrm{mg} / \mathrm{L})$ leads to low concentration in the final product $(0.4 \mathrm{mg} / \mathrm{L})$. This compound, known to be linked to defective ciders with a growth of Brettanomyces anomala (Buron et al., 2012), will not affect the aroma of distillate.

Another way of studying volatile compounds behaviour, is to compare their concentrations in $\mathrm{g} / \mathrm{hL}$ PA at different stages: initial cider, boiler of cider distillations, brouillis, first and second heart, and the concentrations ratio in the second heart and cider $\left(\mathrm{Ht}_{\mathrm{BD} 2} / \mathrm{cider}\right)$ (Table 8). Except methanol and 2-phenylethanol, all alcohols are $100 \%$ recovered in the heart $\left(\mathrm{Ht}_{\mathrm{BD} 2}\right)$. Methanol is transferred at $90 \%$ while 2-phenylethanol only at $5.4 \%$. This last result is really troublesome because this compound is very positive for heart quality and is known as typical compound for cider (Lea \& Drilleau, 2003). Ethyl acetate and 3-methylbutyl acetate are only recovered at $50 \%$ in the heart. This may be explained by the fact that these two compounds tended to concentrate very strongly in the head fractions and that the first $0.2 \mathrm{~L}$ of the $1.6 \mathrm{~L}$ were systematically eliminated. Some esters are found at less than $21 \%$ in the heart (ethyl 2hydroxypropanoate and octanoate, decanoate, propanoate and 2-phenylethyl acetates). As underlined above, these compounds were mainly lost during cider distillation, probably in the heads. These compounds, except ethyl acetate that brings solvent character when too concentrated, are important for fruity aroma. Then, it is problematic to have the main part remaining in the heads, especially acetate esters. It is necessary to avoid ethyl acetate production during fermentation to be able to minimise heads cut and transfer more esters in the heart. Hence, producers should manage the cuts during distillation according to cider composition. For aldehydes it is more difficult to conclude because it has been shown that some of them are formed by reaction (Awad et al., 2017) but also partly lost in the fraction of heads eliminated.

Finally, we determined if the concentration of the compounds in the heart $\left(\mathrm{Ht}_{\mathrm{BD} 2}\right)$ was above their odour perception threshold. For this purpose, thresholds in a $46 \% \mathrm{v} / \mathrm{v}$ hydroalcoholic solution from Gao et al. (2014) and Wang et al. (2014) were reported in Table 9, and key odorant compounds identified by Zhao et al. (2014) were bolded. It can be noted that 13 compounds out of these were quantified in this study. Their concentrations in the heart diluted from $72.2 \% \mathrm{v} / \mathrm{v}$ to $46 \% \mathrm{v} / \mathrm{v}$ and odorant active values (OAV) were calculated (Table 9). Compounds with OAV higher than 10 are, in decreasing order, ethyl octanoate (185.7), propan1-ol (32.9), prop-2-en-ol (27.2), ethyl acetate (15.0), 4-ethylphenol (19.4), 4-ethylguaiacol (12.5), acetaldehyde (12.1), 3-methylbutyl acetate (11.5) and butan-1-ol (10.2). All but butan1-ol are among the key odorant compounds. On the other hand, 2-phenylethanol and 2phenylethyl acetate have OAV levels far under 1 due to their very low recovery in heart. Besides ethyl octanoate and 3-methylbutyl acetate, most of the compounds with high OAV are alcohols not necessarily interesting on the aroma point of view. Indeed, propan-1-ol, prop-2-en-ol, butan- 
1-ol give more alcoholic descriptors when present in too high concentration. Two phenolic compounds have important OAV: 4-ethylphenol and 4-ethylguaiacol; they are related to animal defect in cider and should not be present at too high concentration. The two last compounds are critical for Calvados quality. They are both related to defect as ethyl acetate brings nail polish notes (Swiegers et al., 2005) at high concentration, while acetaldehyde is perceived as ethereal.

\section{Conclusions}

During cider distillation, compositions do not vary too much from the second distillation with head and tail fractions recycling from the previous cider and brouillis distillations. The fractions from brouillis distillations only represent $3.5 \%$ of ethanol in the boiler. For brouillis distillation, we performed one distillation with second fraction recycling which represents $19.4 \%$ of ethanol amount introduced in the boiler.

Among the 28 quantified volatile compounds, 15 have OAV higher than 10, among them nine are common with literature.

Except for 2-phenylethanol, ethyl 2-hydroxypropanoate, 2-phenylethyl acetate and diethyl butanedioate, the quantified compounds are highly concentrated at the beginning of each distillation. However, compounds that bring fruity notes (for example 3-methylbutyl acetate, ethyl octanoate, ethyl decanoate) have a much lower concentration in head fraction of brouillis distillation than cider distillation. It is therefore important to limit elimination of head during cider distillations if the objective is to preserve fruity and floral notes and to limit the presence in cider of negative compounds.

2-phenylethanol, ethyl 2-hydroxypropanoate, 2-phenylethyl acetate and diethyl butanedioate have lower volatilities than other compounds and their concentration increases when the ethanol concentration decreases in the boiler. One part remains in the residue, leading to a loss at each distillation. Only around $5 \%$ of 2-phenylethanol and 2-phenylethyl acetate, $20 \%$ of ethyl 2 hydroxypropanoate and $30 \%$ of diethyl butanedioate are in the heart of the second brouillis distillation $\left(\mathrm{Ht}_{\mathrm{BD} 2}\right)$. Stopping distillations when the ethanol concentration is lower than $2 \% \mathrm{v} / \mathrm{v}$ would probably increase their recovery rate but at the cost of an increase in energy consumption and average distillation duration.

It would be interesting to complete this study with tests in a distillery with an instrumented still (including in-line densimeter) and a large volume of cider in order to control the stability of the double batch distillation. Using a cider of good quality, i.e. poor in ethyl acetate and high in other esters, would confirm the behaviour of volatile flavouring compounds.

\section{Acknowledgments}

This work was supported by FEDER ( $\left.{ }^{\circ} 16 \mathrm{P} 05343\right)$, Région Normandie ( $\left.\mathrm{n}^{\circ} 16 \mathrm{P} 05343\right)$, IDAC (Interprofession Des Appelations Cidricoles) and UNICID (Union Nationale Interprofessionnelle CIDricole) fundings. Authors are grateful to all producers for providing products and their active participation to the project.

\section{References}

Awad, P., Athès, V., Esteban Decloux, M., Ferrari, G., Snakkers, G., Raguenaud, P., \& Giampaoli, P. (2017). Evolution of volatile compounds during the distillation of cognac spirit. Journal of Agriculture and Food Chemistry, 65, 7736-7748. DOI: 10.1021/acs.jafc.7b02406

Buron, N., Guichard, H., Coton, E., Ledauphin J., \& Barillier, D. (2011). Evidence of 4- 
ethylcatechol as one of the main phenolic off-flavour markers in French ciders. Food Chemistry, 125 (2), 542-548. DOI: 10.1016/j.foodchem.2010.09.046

Buron, N., Coton, M., Legendre, P., Ledauphin, J., Kientz-Bouchart, V., Guichard, H., Barillier, D. \& Coton, E. (2012). Implications of Lactobacillus collinoides and Brettanomyces/Dekkera anomala in phenolic off-flavour defects of ciders. International Journal of Food Microbiology, 153 (1-2), 159-165. DOI: 10.1016/j.ijfoodmicro.2011.11.002

Decree $\mathrm{n}^{\circ}$ 2015-12 du 7 janvier 2015. Cahier des charges de l'appellation d'origine contrôlée «Calvados Domfrontais » JORF du 9 janvier 2015. Last view September $15^{\text {th }} 2020$.

Decree n²015-133 du 6 février 2015. Cahier des charges de l'appellation d'origine contrôlée «Calvados» JORF du 8 février 2015. https://www.idacaoc.fr/images/cdc/CdC_Calvados.pdf. Last view September $15^{\text {th }} 2020$.

Decree n²015-134 du 6 février 2015. Cahier des charges de l'appellation d'origine contrôlée «Calvados Pays d'Auge» JORF du 8 février 2015. https://www.idacaoc.fr/images/cdc/CdC_CalvPaysAuge.pdf. Last view September $15^{\text {th }} 2020$.

Douady, A., Puentes, C., Awad, P., \& Esteban-Decloux, M. (2019). Batch distillation of spirits: experimental study and simulation of the behaviour of volatile aroma compounds. Journal of Institute of Brewing, 125:268-283. DOI: 10.1002/jib.560.

Gao, W., Fan, W., \& Xu, Y. (2014). Characterization of the key odorants in light aroma type Chinese liquor by gas chromatography-olfactometry, quantitative measurements, aroma recombination, and omission studies. Journal of Agricultural and Food Chemistry, 62 (25), 5796-5804. DOI: 10.1021/jf501214c.

Guichard, H., Lemesle, S., Ledauphin, J., Barillier, D. \& Picoche, B. (2003). Chemical and Sensorial Aroma Characterization of Freshly Distilled Calvados - Part I: Evaluation of Key Odorants by Olfactometry and Sensory Analysis. Journal of Agricultural and Food Chemistry, 51 (2), 424-432. DOI: 10.1021/jf020372m

Guichard, H., Poupard, P., Legoahec, L., Millet, M., Bauduin, R., \& Le Quéré, J.M. (2019). Brettanomyces anomalus, a double drawback for cider aroma. LWT-Food Science and Technology, 102, 214-222. DOI: 10.1016/j.lwt.2018.12.033

Lea, A.G.H., \& Drilleau, J.F. (2003). Cidermaking. In: Fermented Beverage Production; Second edition, Edited by Lea A.G.H. \& Piggott J.R., Springer Science+Business Media New York, LLC.

Ledauphin, J., Guichard, H., Saint-Clair, J.F., Picoche, B. \& Barillier, D. (2003). Chemical and Sensorial Aroma Characterization of Freshly Distilled Calvados - Part II: Identification of Volatile Compounds and Key odorants. Journal of Agricultural and Food Chemistry, 51 (2), 433-442. DOI: 10.1021/jf020373e

Madrera, R., Blanco Gomis, D., \& Mangas Alonso, J.J. (2003a). Influence of distillation system, oak wood type, and aging time on volatile compounds of cider brandy. Journal of Agriculture and Food Chemistry, 51(19), 5709-5714 DOI: 10.1021/jf034280o

Madrera, R., Blanco Gomis, D., \& Mangas Alonso, J.J. (2003b). Influence of distillation system, oak wood type, and aging time on composition of cider brandy in phenolic and furanic compounds. Journal of Agriculture and Food Chemistry, 51 (27), 7969-7973 DOI: $10.1021 / \mathrm{jf0347618}$ 
Madrera, R., \& Mangas Alonso, J.J. (2005). Typification of cider brandy on the basis of cider used in its manufacture. Journal of Agriculture and Food Chemistry, 53 (27), 3071-3075 DOI: $10.1021 /$ jf0481554

Mangas, J., Rodriguez, R. Moreno, J. \& Blanco, D. (1996a). Changes in the major volatile compounds of cider distillates during maturation. Lebensmittel-Wissenschaft und -Technologie, 29, 357-364 DOI: 0023-6438/96/040357

Mangas, J., Rodríguez, R., Moreno, J., \& Blanco, D. (1996b). Volatiles in distillates of cider aged in american oak wood. Journal of Agricultural and Food Chemistry, 44(1), 268-273 DOI: 0021-8561/96/1444-0268\$12.00/0

Mangas, J., Rodríguez, R., Moreno, J., Suárez, B., \& Blanco, D. (1996c). Evolution of aromatic and furanic congeners in the maturation of cider brandies: a contribution to its characterization. Journal of Agricultural and Food Chemistry, 44 (10), 3303-3307 DOI: S00218561(95)00782-5

OIV, (2014). Recueil des méthodes internationales d'analyse des boissons spiritueuses d'origine vitivinicole. http://www.oiv.int/fr/normes-et-documents-techniques/methodesdanalyse/recueil-des-methodes-internationales-danalyse-des-boissons-spiritueuses-doriginevitivinicole.

Official Journal of the European Communities, 2000. Commission regulation (EC) No 2870/2000 of 19 December 2000 laying down Community reference methods for the analysis of spirits drinks.

https://eur-lex.europa.eu/legal-content/EN/TXT/PDF/?uri=CELEX:32000R2870\&from=FR. Last view September $15^{\text {th }} 2020$.

Puentes, C., Joulia, X., Athès V., \& Esteban-Decloux, M. (2018). Review and thermodynamic modeling with NRTL model of vapor-liquid equilibria (VLE) of aroma compounds highly diluted in ethanol-water mixtures at $101.3 \mathrm{kPa}$. Industrial and Engineering Chemistry Research, 57, 3443-3470 DOI: 10.1021/acs.iecr.7b03857.

Rodriguez Madrera, R., \& Mangas Alonso, J.J. (2005). Typification of Cider Brandy on the Basis of Cider Used in Its Manufacture. Journal of Agriculture and Food Chemistry, 53 (8), 3071-3075 DOI: 10.1021/jf0481554.

Swiegers, J.H., Bartowsky, E.J., Henschke, P.A. \& Pretorius, I.S. (2005). Yeast and bacterial modulation of wine aroma and flavour. Australian Journal of Grape and Wine Research. 11, 139-173. DOI: 10.1111/j.1755-0238.2005.tb00285.x

Versini, G., Franco, M.A., Moser, S., Barchetti, P., \& Manca, G. (2009). Characterisation of apple distillates from native varieties of Sardania island and comparison with other Italian products. Food Chemistry, 113, 1176-1183 DOI: 10.1016/j.foodchem.2008.08.003

Wang, X., Fan, W., \& Xu, Y. (2014). Comparison of aroma compounds in Chinese soy sauce and strong aroma type liquors by gas chromatography-olfactometry, chemical quantitative and odor activity values analysis. European Food Research Technology, 239 (5), 813-825 DOI: $10.1007 / \mathrm{s} 00217-014-2275-\mathrm{Z}$

Xiang, X.F., Lan, Y.B., Gao, X.T., Xie, H., An, Z.Y., Lv, Z.H., Yin-Shi, Duan, C.Q., \& Wu, G.F. (2020). Characterization of odor-active compounds in the head, heart, and tail fractions of freshly distilled spirit from Spine grape (Vitis davidii Foex) wine by gas 
chromatography-olfactometry and gas chromatography-mass spectrometry. Food Research International, 137, DOI: 10.1016/j.foodres.2020.109388

Zhao, Y.P., Tian, T.T., Li, J.M., Zhang, B.C., Yu, Y., Wang, Y.Y., \& Niu, H. (2014). Variations in Main Flavor Compounds of Freshly Distilled Brandy during the Second Distillation. International Journal of Food Engineering, 10 (4): 809-820 DOI: 10.1515/ijfe2014-0123 
Table.1 IUPAC names, usual names, CAS numbers of molecules analysed with three method (A: GC-FID with direct injection (after distillation for ciders and residues); B: Solvent extraction and GC-MS (after distillation for boiler solutions and residues); C: Direct injection and UV-DAD) and minimal and maximal limits of quantification in $\mathrm{mg} / \mathrm{L}$ according to the kind of sample and compounds not quantified.

\begin{tabular}{|c|c|c|c|c|c|c|c|c|c|}
\hline Compounds + (usual name $)$ & CAS & method & $\min$ & $\max$ & Compounds & CAS & method & $\min$ & $\max$ \\
\hline 16 Alcohols $(\mathrm{mg} / \mathrm{L})$ & & & & & Esters $(m g / L)$ & & & & \\
\hline methanol & $67-56-1$ & A & 6.87 & 11.22 & butyl acetate & $123-86-4$ & A & 0.41 & 0.66 \\
\hline propan-1-ol & $71-23-8$ & A & 10.88 & 17.77 & butyl acetate & $123-86-4$ & $\mathrm{~B}$ & 0.02 & 0.52 \\
\hline 2-methylpropan-1-ol (isobutanol) & $78-83-1$ & A & 6.90 & 11.26 & ethyl 2-methylbutanoate & $7452-79-1$ & B & 0.03 & 0.20 \\
\hline 2-methylbutan-1-ol (amyl alcohol) & $137-32-6$ & A & 1.13 & 1.85 & ethyl 3-methylbutanoate (ethyl isovalerate) & $108-64-5$ & B & 0.02 & 0.15 \\
\hline 3-methylbutan-1-ol (isoamyl alcohol) & $123-51-3$ & A & 14.92 & 24.36 & ethyl pentanoate (ethyl valerate) & $539-82-2$ & B & 0.01 & 0.08 \\
\hline butan-2-ol & $78-92-2$ & A & 6.58 & 10.74 & pentyl acetate (amyl acetate) & $628-63-7$ & B & 0.03 & 0.49 \\
\hline butan-1-ol & $71-36-3$ & A & 1.44 & 2.35 & ethyl hexanoate (ethyl caproate) & $123-66-0$ & B & 0.02 & 0.18 \\
\hline hexan-1-ol & $111-27-3$ & A & 1.14 & 1.86 & {$[(\mathrm{Z})$-hex-3-enyl $]$ acetate } & $3681-71-8$ & B & 0.04 & 0.42 \\
\hline 2-phenylethanol & $60-12-8$ & A & 2.98 & 4.87 & hexyl acetate & $142-92-7$ & A & 0.46 & 0.74 \\
\hline (Z)-hex-3-en-1-ol (cis-3-hexenol) & $928-96-1$ & A & 0.50 & 0.81 & hexyl acetate & $142-92-7$ & B & 0.02 & 0.82 \\
\hline pentan-1-ol & $71-41-0$ & A & 0.25 & 0.41 & ethyl heptanoate & $106-30-6$ & $\mathrm{~B}$ & 0.02 & 0.14 \\
\hline oct-1-en-3-ol & $3391-86-4$ & $\mathrm{~A}$ & 0.35 & 0.56 & ethyl 3-methylsulfanyl propanoate & $13327-56-5$ & B & 0.01 & 0.10 \\
\hline octan-1-ol & $111-87-5$ & $\mathrm{~B}$ & 0.15 & 7.78 & ethyl benzoate & $93-89-0$ & A & 0.21 & 0.34 \\
\hline pentan-3-ol & $584-02-1$ & A & 0.22 & 0.36 & ethyl benzoate & $93-89-0$ & $\mathrm{~B}$ & 0.01 & 0.10 \\
\hline pentan-3-ol & $584-02-1$ & $\mathrm{~B}$ & 0.05 & 0.37 & 3-methylbutyl octanoate (isoamyl caprylate) & 2035-99-6 & $\mathrm{B}$ & 0.01 & 0.07 \\
\hline 6-methylhept-5-en-2-ol & $1569-60-4$ & $\mathrm{~B}$ & 0.02 & 1.25 & 2-methylpropyl decanoate (isobutyl caprate) & $30673-38-2$ & A & 0.33 & 0.55 \\
\hline prop-2-en-1-ol (allyl alcohol) & $107-18-6$ & A & 2.45 & 3.99 & 2-methylpropyl decanoate (isobutyl caprate) & $30673-38-2$ & $\mathrm{~B}$ & 0.01 & 0.07 \\
\hline 37 Esters $(\mathrm{mg} / \mathrm{L})$ & & & & & 3-methylbutyl decanoate (isoamyl caprate) & $2306-91-4$ & A & 0.34 & 0.55 \\
\hline ethyl formate & $109-94-4$ & A & 1.18 & 1.93 & 3-methylbutyl decanoate(isoamyl caprate) & $2306-91-4$ & $\mathrm{~B}$ & 0.01 & 0.07 \\
\hline ethyl acetate & $141-78-6$ & A & 13.18 & 21.53 & 2-phenylethyl hexanoate (2-phenylethyl caproate) & $6290-37-5$ & A & 0.21 & 0.34 \\
\hline ethyl butanoate (ethyl butyrate) & $105-54-4$ & A & 0.50 & 0.81 & 2-phenylethyl hexanoate (2-phenylethyl caproate) & $6290-37-5$ & $\mathrm{~B}$ & 0.02 & 0.14 \\
\hline ethyl butanoate (ethyl butyrate) & $105-54-4$ & $\mathrm{~B}$ & 0.04 & 0.74 & ethyl tetradecanoate (ethyl myristate) & $124-06-1$ & A & 0.49 & 0.80 \\
\hline 3-methylbutyl acetate (isoamyl acetate) & $123-92-2$ & A & 0.50 & 0.81 & ethyl tetradecanoate (ethyl myristate) & $124-06-1$ & $\mathrm{~B}$ & 0.02 & 0.14 \\
\hline 3-methylbutyl acetate (isoamyl acetate) & $123-92-2$ & $\mathrm{~B}$ & 0.06 & 1.90 & 3-methylbutyl dodecanoate (isoamyl laurate) & $6309-51-9$ & B & 0.01 & 0.09 \\
\hline ethyl 2-hydroxypropanoate (ethyl lactate) & $97-64-3$ & A & 10.36 & 16.92 & 2-phenylethyl octanoate (2-phenylethyl caprylate) & $5457-70-5$ & A & 0.36 & 0.59 \\
\hline ethyl octanoate (ethyl caprylate) & $106-32-1$ & A & 0.50 & 0.81 & 2-phenylethyl octanoate (2-phenylethyl caprylate) & $5457-70-5$ & $\mathrm{~B}$ & 0.01 & 0.06 \\
\hline ethyl octanoate (ethyl caprylate) & $106-32-1$ & $\mathrm{~B}$ & 0.14 & 1.02 & ethyl hexadecanoate (ethyl palmitate) & $628-97-7$ & A & 0.52 & 0.85 \\
\hline ethyl decanoate (ethyl caprate) & $110-38-3$ & A & 0.50 & 0.81 & ethyl hexadecanoate (ethyl palmitate) & $628-97-7$ & $\mathrm{~B}$ & 0.06 & 0.43 \\
\hline ethyl decanoate (ethyl caprate) & $110-38-3$ & $\mathrm{~B}$ & 0.02 & 0.16 & ethyl octadecanoate(ethyl stearate) & $111-61-5$ & B & 0.00 & 0.38 \\
\hline diethyl butanedioate (diethyl succinate) & $123-25-1$ & A & 0.59 & 0.96 & 7 Aldehydes $(m g / L)$ & & & & \\
\hline diethyl butanedioate (diethyl succinate) & $123-25-1$ & $\mathrm{~B}$ & 0.07 & 1.54 & prop-2-enal (acrolein) & $107-02-8$ & A & 0.58 & 0.95 \\
\hline 1-phenylethyl acetate (ethyl phenylacetate) & $101-97-3$ & A & 0.58 & 0.95 & acetaldehyde (ethanal) & $75-07-7$ & A & 9.21 & 15.04 \\
\hline 2-phenylethyl acetate (phenethyl acetate) & $103-45-7$ & A & 0.33 & 0.54 & 1,1-diethoxyethane (acetal) & $105-57-7$ & A & 2.41 & 3.94 \\
\hline 2-phenylethyl acetate (phenethyl acetate) & $103-45-7$ & $\mathrm{~B}$ & 0.01 & 0.08 & furan-2-carbaldehyde (furfural) & $98-01-1$ & A & 0.56 & 0.91 \\
\hline ethyl dodecanoate (ethyl laurate) & $106-33-2$ & A & 0.49 & 0.80 & 2-methylpropanal (isobutanal) & $78-84-2$ & A & 0.36 & 0.59 \\
\hline ethyl dodecanoate (ethyl laurate) & $106-33-2$ & B & 0.03 & 0.19 & nonanal & $124-19-6$ & B & 0.05 & 0.39 \\
\hline ethyl 3-hydroxybutanoate & $5405-41-4$ & A & 0.35 & 0.56 & decanal & $112-31-2$ & B & 0.06 & 0.64 \\
\hline ethyl 2-hydroxyhexanoate & $52089-55-1$ & A & 0.24 & 0.39 & 6 Phenols $(\mathrm{mg} / \mathrm{L})$ & & & & \\
\hline ethyl 2-hydroxyhexanoate & $52089-55-1$ & B & 0.10 & 6.87 & 4-ethylcatechol & $1124-39-6$ & $\mathrm{C}$ & 0.09 & 0.17 \\
\hline
\end{tabular}


ethyl furan-2-carboxylate (ethyl fuorate) $\quad$ 1335-40-6 ethyl propanoate (ethyl propionate) $105-37-3$

ethyl 2-methylpropanoate (ethyl isobutyrate) 97-62-1

2-methylpropyl acetate (isobutyl acetate)

$110-19-0$

2-methylpropyl acetate (isobutyl acetate)

A
B
B
A
B

$0.28 \quad 0.46 \quad$ 4-vinylphenol

$0.09 \quad 0.63 \quad 4$-vinylguaiaco

$0.02 \quad 0.13 \quad$ 4-ethylphenol

$0.31 \quad 0.51 \quad$ 4-ethylguaiacol

$0.04 \quad 0.28 \quad 4$-vinyl anisol

\begin{tabular}{llll}
$2628-17-3$ & C & 0.09 & 0.17 \\
$7786-61-0$ & C & 0.09 & 0.17 \\
$123-07-9$ & C & 0.09 & 0.17 \\
$2785-89-9$ & C & 0.09 & 0.17 \\
$637-69-4$ & B & 0.01 & 0.08 \\
\hline
\end{tabular}

2628-17-3

$637-69-4$

Phenols are named with their common names as it is more understandable by cider industry 
Table 2 Cider distillations data: mass (m), ABV and duration (Dt) for the different fractions obtained during the distillation of Calvados

\begin{tabular}{|c|c|c|c|c|c|c|c|c|c|c|c|c|c|c|c|}
\hline & \multicolumn{2}{|c|}{ into boiler } & \multicolumn{3}{|c|}{ Hd (head) } & \multicolumn{3}{|c|}{ B (brouillis) } & \multicolumn{3}{|c|}{$\mathrm{T}$ (tail) } & \multicolumn{3}{|c|}{ D (dead volume) } & $\mathrm{R}$ (residue) \\
\hline & $\mathrm{m}$ & $\mathrm{ABV}$ & $\mathrm{m}$ & $\mathrm{ABV}$ & Dt & $\mathrm{m}$ & $\mathrm{ABV}$ & Dt & $\mathrm{m}$ & $\mathrm{ABV}$ & Dt & $\mathrm{m}$ & $\mathrm{ABV}$ & $\mathrm{m}$ & $\mathrm{ABV}$ \\
\hline & $\mathrm{kg}$ & $\% \mathrm{v} / \mathrm{v}$ & $\mathrm{kg}$ & $\% \mathrm{v} / \mathrm{v}$ & $\min$ & $\mathrm{kg}$ & $\% \mathrm{v} / \mathrm{v}$ & $\min$ & $\mathrm{kg}$ & $\% \mathrm{v} / \mathrm{v}$ & $\min$ & $\mathrm{kg}$ & $\% \mathrm{v} / \mathrm{v}$ & $\mathrm{kg}$ & $\% \mathrm{v} / \mathrm{v}$ \\
\hline CD1 & 100.0 & 7.00 & 1.50 & 46.7 & 30.5 & 15.90 & 31.6 & 210.0 & 10.35 & 6.4 & 125.5 & 1.10 & 1.8 & 71.15 & 0.1 \\
\hline $\mathrm{CD} 2$ & 91.6 & 7.30 & 1.48 & 52.3 & 15.8 & 16.20 & 32.4 & 228.0 & 10.40 & 6.1 & 101.0 & 1.35 & 1.8 & 62.17 & 0.0 \\
\hline CD3 & 93.0 & 7.00 & 1.48 & 52.0 & 15.5 & 16.05 & 32.4 & 231.0 & 10.20 & 6.4 & 100.5 & 1.00 & 1.9 & 64.22 & 0.0 \\
\hline CD4 & 93.4 & 7.15 & 1.48 & 51.8 & 14.3 & 16.45 & 32.6 & 223.3 & 10.35 & 6.4 & 101.0 & 1.00 & 1.9 & 64.12 & 0.2 \\
\hline CD5 & 92.6 & 7.20 & 1.48 & 51.7 & 14.8 & 16.50 & 32.4 & 220.0 & 10.25 & 6.3 & 98.5 & 1.00 & 1.9 & 63.37 & 0.0 \\
\hline CD6 & 92.7 & 7.30 & 1.48 & 52.8 & 13.9 & 16.70 & 32.6 & 215.0 & 10.40 & 6.5 & 97.5 & 1.00 & 1.9 & 63.12 & 0.0 \\
\hline CD7 & 94.3 & 7.20 & 1.48 & 53.0 & 14.7 & 16.80 & 32.8 & 219.5 & 10.40 & 6.3 & 95.0 & 1.07 & 1.9 & 64.51 & 0.1 \\
\hline CD8 & 93.7 & 7.30 & 1.48 & 52.6 & 14.2 & 16.65 & 32.7 & 216.7 & 10.45 & 6.3 & 96.5 & 1.03 & 1.9 & 64.09 & 0.1 \\
\hline CD9 & 93.0 & 7.50 & 1.48 & 52.0 & 14.3 & 16.57 & 33,1 & 223.1 & 10.56 & 6,3 & 97.0 & 1.00 & 1.9 & 63.34 & 0.0 \\
\hline \multicolumn{16}{|c|}{ CD2-CD9 } \\
\hline Mean & 93.02 & 7.24 & 1.48 & 52.3 & 14.7 & 16.49 & 32.56 & 222.1 & 10.38 & 6.33 & 98.4 & 1.06 & 1.89 & 63.62 & 0.1 \\
\hline SD & 0.80 & 0.15 & 0.00 & 0.5 & 0.7 & 0.25 & 0.16 & 5.4 & 0.11 & 0.13 & 2.3 & 0.12 & 0.04 & 0.77 & 0.1 \\
\hline
\end{tabular}

Table 3 Brouillis distillations data: mass (m), ABV and duration (Dt) for the different fractions

\begin{tabular}{|c|c|c|c|c|c|c|c|c|c|c|c|c|c|c|c|c|c|c|}
\hline & \multicolumn{2}{|c|}{ into boiler } & \multicolumn{3}{|c|}{ Hd (head) } & \multicolumn{3}{|c|}{ Ht (Heart) } & \multicolumn{3}{|c|}{ S (second) } & \multicolumn{3}{|c|}{$\mathrm{T}$ (tail) } & \multicolumn{2}{|c|}{$\begin{array}{l}\mathrm{D} \text { (dead } \\
\text { volume) }\end{array}$} & \multicolumn{2}{|c|}{ R (residue) } \\
\hline & $\mathrm{m}$ & $\mathrm{ABV}$ & $\mathrm{m}$ & $\mathrm{ABV}$ & $\mathrm{Dt}$ & $\mathrm{m}$ & $\mathrm{ABV}$ & $\mathrm{Dt}$ & $\mathrm{m}$ & $\mathrm{ABV}$ & $\mathrm{Dt}$ & $\mathrm{m}$ & $\mathrm{ABV}$ & $\mathrm{Dt}$ & $\mathrm{m}$ & $\mathrm{ABV}$ & $\mathrm{m}$ & $\mathrm{ABV}$ \\
\hline & $\mathrm{kg}$ & $\% \mathrm{v} / \mathrm{v}$ & $\mathrm{kg}$ & $\% \mathrm{v} / \mathrm{v}$ & $\min$ & $\mathrm{kg}$ & $\% \mathrm{v} / \mathrm{v}$ & $\min$ & $\mathrm{kg}$ & $\% \mathrm{v} / \mathrm{v}$ & $\min$ & $\mathrm{kg}$ & $\% \mathrm{v} / \mathrm{v}$ & $\min$ & $\mathrm{kg}$ & $\% \mathrm{v} / \mathrm{v}$ & $\mathrm{kg}$ & $\% \mathrm{v} / \mathrm{v}$ \\
\hline BD1 & 80.70 & 32.10 & 1.39 & 77.0 & 8.6 & 24.05 & 72.2 & 220.3 & 13.50 & 36.8 & 103.3 & 5.00 & 5.3 & 35.2 & 1.30 & 1.8 & 35.46 & 0.1 \\
\hline $\mathrm{BD} 2$ & 76.67 & 33.30 & 1.39 & 77.3 & 9.9 & 26.00 & 72.0 & 233.3 & 10.55 & 36.8 & 86.8 & 5.70 & 6.3 & 35.3 & 1.19 & 1.9 & 31.84 & 0.0 \\
\hline
\end{tabular}


Table 4 Concentration of volatile compounds ( $\mathrm{mg} / \mathrm{L}$ ) in fractions obtained during cider distillations CD2 to CD9

\begin{tabular}{|c|c|c|c|c|c|c|c|c|c|c|c|c|c|}
\hline & \multicolumn{2}{|c|}{ into boiler } & \multicolumn{2}{|c|}{ Head } & \multicolumn{2}{|c|}{ Brouillis } & \multicolumn{2}{|c|}{ Tail } & \multicolumn{2}{|c|}{$\begin{array}{c}\text { Dead } \\
\text { volume }\end{array}$} & \multicolumn{2}{|c|}{ Residue } & \multirow{2}{*}{$\begin{array}{l}\text { Balance } \\
\text { diff*** }\end{array}$} \\
\hline & Mean & $S D$ & Mean & $S D$ & Mean & $S D$ & Mean & $S D$ & Mean & $S D$ & Mean & $S D$ & \\
\hline $\mathrm{ABV}(\% \mathrm{v} / \mathrm{v})$ & 7.2 & 0.1 & 52.3 & 0.5 & 32.6 & 0.2 & 6.3 & 0.1 & 1.9 & 0.0 & 0.1 & 0.1 & $-2.0 \%$ \\
\hline \multicolumn{14}{|l|}{ Alcohols $(\mathrm{mg} / \mathrm{L})$} \\
\hline methanol & 56.0 & 1.6 & 255.7 & 2.8 & 214.1 & 4.3 & 88.5 & 2.0 & 49.7 & 0.8 & 5.2 & 0.0 & $-0.4 \%$ \\
\hline propan-1-ol & 270.1 & 2.7 & 2651.7 & 21.6 & 1199.2 & 12.9 & 83.8 & 1.4 & 17.1 & 0.0 & 8.2 & 0.0 & $0.4 \%$ \\
\hline 2-methylpropan-1-ol & 30.1 & 0.6 & 512.3 & 5.0 & 128.6 & 2.7 & 4.7 & 0.0 & 5.1 & 0.0 & 5.2 & 0.0 & $17 \%$ \\
\hline 2-methylbutan-1-ol & 31.3 & 0.5 & 627.9 & 4.1 & 129.7 & 3.0 & 0.8 & 0.0 & 0.8 & 0.0 & 0.9 & 0.0 & $9 \%$ \\
\hline 3-methylbutan-1-ol & 103.0 & 1.4 & 1869.0 & 11.3 & 452.0 & 9.1 & 10.1 & 0.0 & 11.1 & 0.0 & 11.3 & 0.0 & $16 \%$ \\
\hline butan-2-ol & 71.5 & 1.6 & 1309.3 & 19.3 & 311.1 & 7.3 & 4.5 & 0.0 & 4.9 & 0.0 & 5.0 & 0.0 & $13 \%$ \\
\hline butan-1-ol & 4.3 & 0.1 & 52.0 & 0.4 & 19.3 & 0.3 & 0.5 & 0.0 & 0.5 & 0.0 & 0.5 & 0.0 & $10 \%$ \\
\hline hexan-1-ol & 2.9 & 0.1 & 58.9 & 0.3 & 11.9 & 0.3 & 0.4 & 0.0 & 0.4 & 0.0 & 0.4 & 0.0 & $16 \%$ \\
\hline 2-phenylethanol & 54.3 & 2.6 & 47.7 & 0.6 & 93.8 & 1.7 & 127.5 & 2.7 & 129.5 & 1.8 & 40.7 & 3.5 & $9 \%$ \\
\hline (Z)-hex-3-en-1-ol* & 0.2 & 0.0 & 1.5 & 0.1 & 0.8 & 0.1 & 0.2 & 0.0 & 0.2 & 0.0 & 0.2 & 0.0 & $68 \%$ \\
\hline pentan-1-ol* & 0.2 & 0.0 & 2.9 & 0.1 & 0.8 & 0.0 & 0.1 & 0.0 & 0.1 & 0.0 & 0.1 & 0.0 & $41 \%$ \\
\hline prop-2-en-1-ol & 5.5 & 0.1 & 29.9 & 0.6 & 22.5 & 0.6 & 6.3 & 0.2 & 1.9 & 0.0 & 0.9 & 0.0 & $6 \%$ \\
\hline \multicolumn{14}{|l|}{ Esters $(\mathrm{mg} / \mathrm{L})$} \\
\hline ethyl acetate & 223.5 & 19.3 & 9877.1 & 925.6 & 436.3 & 38.5 & 17.8 & 0.0 & 19.5 & 0.0 & 20.0 & 0.0 & $14 \%$ \\
\hline 3-methylbutyl acetate & 1.2 & 0.3 & 58.9 & 8.8 & 1.0 & 0.1 & 0.4 & 0.0 & 0.3 & 0.1 & 0.2 & 0.1 & $12 \%$ \\
\hline ethyl 2-hydroxypropanoate & 268.5 & 12.2 & 404.6 & 9.0 & 550.6 & 19.4 & 482.7 & 20.8 & 504.9 & 13.6 & 108.0 & 7.2 & $-13 \%$ \\
\hline ethyl octanoate* & 2.9 & 0.2 & 54.7 & 9.7 & 2.8 & 0.2 & 1.5 & 0.1 & 1.4 & 0.1 & 0.3 & 0.1 & $-40 \%$ \\
\hline ethyl decanoate & 0.4 & 0.0 & 19.7 & 2.6 & 0.1 & 0.0 & 0.2 & 0.0 & 0.2 & 0.0 & 0.2 & 0.0 & $24 \%$ \\
\hline diethyl butanedioate & 6.3 & 0.3 & 12.0 & 0.4 & 16.7 & 0.7 & 12.1 & 0.7 & 8.8 & 0.3 & 1.5 & 0.1 & $-13 \%$ \\
\hline 2-phenylethyl acetate* & 0.2 & 0.0 & 1.0 & 0.0 & 0.1 & 0.0 & 0.1 & 0.0 & 0.1 & 0.0 & 0.0 & 0.0 & $-67 \%$ \\
\hline ethyl 3-hydroxybutanoate* & 0.3 & 0.1 & 2.4 & 0.2 & 1.0 & 0.1 & 0.5 & 0.2 & 0.1 & 0.0 & 0.3 & 0.0 & $76 \%$ \\
\hline ethyl propanoate & 15.6 & 2.0 & 591.4 & 70.9 & 5.9 & 0.6 & 3.6 & 0.3 & 1.8 & 0.4 & 0.1 & 0.0 & $-28 \%$ \\
\hline \multicolumn{14}{|l|}{ Aldehydes $(m g / L)$} \\
\hline Acetaldehyde* & 4.0 & 1.4 & 111.2 & 11.2 & 19.1 & 1.1 & 6.6 & 0.0 & 3.4 & 0.0 & 4.5 & 1.8 & $124 \%$ \\
\hline 1,1-diethoxyethane* & 1.9 & 0.0 & 121.5 & 10.3 & 8.7 & 0.6 & 1.3 & 0.5 & 1.2 & 0.5 & 1.4 & 0.5 & $139 \%$ \\
\hline 2-methylpropanal* & 0.2 & 0.0 & 4.7 & 1.2 & 0.6 & 0.1 & 0.4 & 0.2 & 0.3 & 0.0 & 0.1 & 0.0 & $112 \%$ \\
\hline \multicolumn{14}{|l|}{ Phenols $(m g / L)$} \\
\hline 4-ethylcatechol & 19.6 & 1.0 & 8.6 & 1.1 & 0.3 & 0.0 & 0.4 & 0.0 & 0.6 & 0.0 & 29.5 & 0.8 & $0 \%$ \\
\hline 4-ethylphenol & 3.4 & 0.3 & 4.6 & 0.2 & 7.4 & 0.3 & 8.2 & 0.4 & 7.1 & 0.3 & 1.7 & 0.1 & $2 \%$ \\
\hline 4-ethylguaiacol & 0.7 & 0.1 & 1.6 & 0.1 & 2.1 & 0.1 & 1.2 & 0.1 & 0.7 & 0.0 & 0.0 & 0.0 & $-18 \%$ \\
\hline 4-vinylanisol* & 0.0 & 0.0 & 0.1 & 0.0 & 0.0 & 0.0 & 0.0 & 0.0 & 0.0 & 0.0 & 0.0 & 0.0 & $99 \%$ \\
\hline
\end{tabular}

* compounds with the balance higher than $\pm 25 \%$

**The balance difference was calculated according to Eq. 1 
Table 5 Concentration of volatile compounds $(\mathrm{mg} / \mathrm{L})$ in fractions obtained during the two brouillis distillation

\begin{tabular}{|c|c|c|c|c|c|c|c|c|c|c|c|c|c|c|c|c|}
\hline & $\begin{array}{r}\text { into } \\
\text { boiler }\end{array}$ & $\mathrm{Hd}_{\mathrm{BD} 1}$ & $\mathrm{Ht}_{\mathrm{BD} 1}$ & $\mathrm{~S}_{\mathrm{BD} 1}$ & $\mathrm{~T}_{\mathrm{BD} 1}$ & $\mathrm{Dv}_{\mathrm{BD} 1}$ & $\mathrm{R}_{\mathrm{BD} 1}$ & $\begin{array}{r}\text { Balance } \\
\text { diff. }\end{array}$ & $\begin{array}{r}\text { into } \\
\text { boiler }\end{array}$ & $\mathrm{Hd}_{\mathrm{BD} 2}$ & $\mathrm{Ht}_{\mathrm{BD} 2}$ & $\mathrm{~S}_{\mathrm{BD} 2}$ & $\mathrm{~T}_{\mathrm{BD} 2}$ & $\mathrm{D} v_{\mathrm{BD} 2}$ & $\mathrm{R}_{\mathrm{BD} 2}$ & $\begin{array}{r}\text { Balance } \\
\text { diff.** }\end{array}$ \\
\hline *Fraction ABV (\%v/v) & 32.1 & 77.0 & 72.2 & 36.8 & 5.3 & 1.8 & 0.1 & $-1.8 \%$ & 33.3 & 77.3 & 72.2 & 36.8 & 6.3 & 1.9 & 0.0 & $1.2 \%$ \\
\hline \multicolumn{17}{|l|}{ Alcohols $(\mathrm{mg} / \mathrm{L})$} \\
\hline methanol & 206.2 & 418.2 & 397.3 & 311.5 & 136.3 & 59.5 & 5.2 & $-2.6 \%$ & 232.5 & 457.1 & 437.2 & 339.8 & 111.9 & 71.4 & 5.2 & $-1.7 \%$ \\
\hline propan-1-ol & 1197.2 & 3090.2 & 3030.8 & 1059.0 & 52.2 & 8.1 & 8.2 & $2.6 \%$ & 1165.6 & 2864.5 & 2793.0 & 891.1 & 41.7 & 17.1 & 8.2 & $4.5 \%$ \\
\hline 2-methylpropan-1-ol & 125.2 & 435.8 & 343.3 & 33.1 & 4.7 & 5.1 & 5.2 & $2.3 \%$ & 112.8 & 364.3 & 281.3 & 20.5 & 4.7 & 5.1 & 5.2 & $3.2 \%$ \\
\hline 2-methylbutan-1-ol & 125.8 & 364.0 & 348.5 & 31.6 & 0.8 & 0.8 & 0.9 & $0.1 \%$ & 112.4 & 299.7 & 288.8 & 18.6 & 0.8 & 1.8 & 0.9 & $2.8 \%$ \\
\hline 3-methylbutan-1-ol & 441.9 & 1094.6 & 1216.0 & 161.3 & 10.1 & 11.1 & 11.3 & $1.5 \%$ & 401.4 & 912.4 & 1018.8 & 103.1 & 10.1 & 11.1 & 11.3 & $3.1 \%$ \\
\hline butan-2-ol & 300.9 & 1188.9 & 832.4 & 65.0 & 4.5 & 4.9 & 5.0 & $1.9 \%$ & 270.7 & 995.3 & 678.7 & 39.0 & 4.5 & 4.9 & 5.0 & $2.7 \%$ \\
\hline butan-1-ol & 19.2 & 43.7 & 48.8 & 13.0 & 0.5 & 0.5 & 0.5 & $-0.2 \%$ & 18.1 & 38.7 & 43.5 & 10.1 & 0.5 & 0.5 & 0.5 & $1.8 \%$ \\
\hline hexan-1-ol & 11.6 & 20.8 & 31.5 & 4.4 & 0.4 & 0.4 & 0.4 & $-0.6 \%$ & 10.5 & 17.1 & 26.7 & 2.6 & 0.4 & 0.4 & 0.4 & $2.3 \%$ \\
\hline 2-phenylethanol & 91.6 & 5.3 & 20.3 & 132.0 & 228.6 & 201.8 & 94.6 & $-6.4 \%$ & 100.8 & 4.9 & 25.1 & 157.4 & 197.7 & 229.8 & 112.0 & $-7.3 \%$ \\
\hline (Z)-hex-3-en-1-ol & 0.9 & 0.4 & 1.5 & 1.2 & 0.2 & 0.2 & 0.2 & $-6.8 \%$ & 0.9 & 0.4 & 1.8 & 1.2 & 0.2 & 0.2 & 0.2 & $7.2 \%$ \\
\hline pentan-1-ol & 0.8 & 2.0 & 2.1 & 0.4 & 0.1 & 0.1 & 0.1 & $1.4 \%$ & 0.7 & 1.7 & 1.8 & 0.4 & 0.1 & 0.1 & 0.1 & $6.4 \%$ \\
\hline prop-2-en-1-ol & 21.6 & 37.0 & 41.4 & 35.5 & 13.4 & 5.0 & 0.9 & $-0.8 \%$ & 25.0 & 41.0 & 47.0 & 40.1 & 10.3 & 6.2 & 0.9 & $-0.4 \%$ \\
\hline \multicolumn{17}{|l|}{ Esters $(m g / L)$} \\
\hline ethyl acetate & 380.4 & 5823.1 & 836.4 & 26.0 & 17.8 & 19.5 & 20.0 & $4.3 \%$ & 392.7 & 5527.1 & 765.5 & 26.0 & 17.8 & 19.5 & 20.0 & $3.4 \%$ \\
\hline 3-methylbutyl acetate* & 0.8 & 8.7 & 1.9 & 0.2 & 0.4 & 0.2 & 0.2 & $16.4 \%$ & 0.7 & 8.8 & 1.7 & 0.2 & 0.4 & 0.4 & 0.4 & $41.4 \%$ \\
\hline ethyl 2-hydroxypropanoate & 531.2 & 142.3 & 353.1 & 1111.9 & 1281.7 & 980.6 & 230.6 & $-6.9 \%$ & 654.1 & 164.2 & 466.7 & 1452.4 & 1006.9 & 1126.2 & 308.3 & $-10.0 \%$ \\
\hline ethyl octanoate & 2.8 & 4.6 & 2.9 & 6.9 & 5.7 & 3.0 & 0.2 & $-2.9 \%$ & 3.6 & 3.6 & 3.8 & 9.9 & 3.8 & 3.8 & 0.2 & $-11.1 \%$ \\
\hline ethyl decanoate* & 0.1 & 2.8 & 0.8 & 0.2 & 0.2 & 0.2 & 0.2 & $286.8 \%$ & 0.1 & 1.9 & 0.4 & 0.2 & 0.2 & 0.2 & 0.2 & $163.7 \%$ \\
\hline diethyl butanedioate & 15.7 & 2.9 & 10.7 & 46.8 & 50.4 & 22.2 & 3.1 & $2.5 \%$ & 22.1 & 3.8 & 16.7 & 69.6 & 32.5 & 32.3 & 4.4 & $-7.8 \%$ \\
\hline 2-phenylethyl acetate* & 0.1 & 0.3 & 0.1 & 0.3 & 0.1 & 0.1 & 0.9 & $263.9 \%$ & 0.2 & 0.2 & 0.1 & 0.3 & 0.1 & 0.1 & 1.3 & $281.4 \%$ \\
\hline ethyl 3-hydroxybutanoate* & 0.9 & 1.2 & 1.8 & 1.2 & 1.0 & 0.8 & 0.9 & $-39.2 \%$ & 0.9 & 1.0 & 1.5 & 1.3 & 0.8 & 0.9 & 1.5 & $56.4 \%$ \\
\hline ethyl propanoate* & 4.9 & 194.2 & 4.9 & 1.7 & 2.1 & 1.2 & 1.2 & $26.3 \%$ & 5.8 & 259.5 & 4.6 & 2.0 & 3.6 & 2.1 & 1.6 & $40.4 \%$ \\
\hline \multicolumn{17}{|l|}{ Aldehydes $(m g / L)$} \\
\hline acetaldehyde & 17.5 & 219.2 & 26.6 & 2.1 & 3.1 & 3.4 & 3.5 & $-15.0 \%$ & 16.3 & 201.0 & 22.8 & 2.1 & 3.1 & 3.4 & 3.5 & $-11.8 \%$ \\
\hline 1,1-diethoxyethane* & 7.6 & 129.3 & 39.1 & 0.6 & 0.8 & 0.9 & 0.9 & $105.9 \%$ & 7.5 & 116.8 & 32.6 & 0.6 & 0.8 & 0.9 & 0.9 & $98.5 \%$ \\
\hline 2-methylpropanal & 0.6 & 12.1 & 0.8 & 0.1 & 0.1 & 0.1 & 0.1 & $-9.5 \%$ & 0.5 & 10.0 & 0.3 & 0.1 & 0.1 & 0.1 & 0.1 & $-21.3 \%$ \\
\hline \multicolumn{17}{|l|}{ Phenols (mg/L) } \\
\hline 4-ethylcatechol & 0.2 & 3.2 & 0.4 & 0.0 & 0.0 & 0.0 & 0.0 & $0.8 \%$ & 0.2 & 3.1 & 0.4 & 0.0 & 0.0 & 0.0 & 0.1 & $5.9 \%$ \\
\hline 4-ethylphenol & 6.9 & 0.5 & 2.5 & 16.9 & 20.0 & 16.2 & 3.5 & $-4.9 \%$ & 9.4 & 0.6 & 3.8 & 24.1 & 27.4 & 23.0 & 5.0 & $-3.5 \%$ \\
\hline 4-ethylguaiacol & 1.9 & 0.3 & 1.5 & 6.4 & 3.5 & 1.8 & 0.1 & $-4.6 \%$ & 2.9 & 0.4 & 2.4 & 10.1 & 5.6 & 2.9 & 0.2 & $-3.3 \%$ \\
\hline 4-vinylanisol & 0.0 & 0.0 & 0.0 & 0.0 & 0.0 & 0.0 & 0.0 & $-9.9 \%$ & 0.0 & 0.0 & 0.0 & 0.0 & 0.0 & 0.0 & 0.0 & $-7.5 \%$ \\
\hline
\end{tabular}

* compounds with mass balance higher than $\pm 25 \%$

**The balance difference was calculated according to Eq.2 
Table 6 Compounds distribution during cider distillations (CD2 to CD9) into the different fractions.

\begin{tabular}{|c|c|c|c|c|}
\hline $\begin{array}{l}\% \text { Exit } \\
\Sigma(\mathrm{Hd}+\mathrm{B}+\mathrm{T}+\mathrm{Dv}+\mathrm{R})\end{array}$ & $\mathrm{Hd}$ & $\mathrm{B}$ & $\mathrm{T}$ & $\mathrm{Dv}+\mathrm{R}$ \\
\hline ethanol & $11.7 \%$ & $78.4 \%$ & $9.2 \%$ & $0.7 \%$ \\
\hline \multicolumn{5}{|c|}{ Alcohols } \\
\hline methanol & $7.6 \%$ & $68.1 \%$ & $17.2 \%$ & $7.1 \%$ \\
\hline propan-1-ol & $16.1 \%$ & $78.5 \%$ & $3.3 \%$ & $2.1 \%$ \\
\hline 2-methylpropan-1-ol & $24.0 \%$ & $64.7 \%$ & $1.4 \%$ & $9.9 \%$ \\
\hline 2-methylbutan-1-ol & $30.5 \%$ & $67.6 \%$ & $0.2 \%$ & $1.7 \%$ \\
\hline 3-methylbutan-1-ol & $25.8 \%$ & $67.0 \%$ & $0.9 \%$ & $6.3 \%$ \\
\hline butan-2-ol & $26.8 \%$ & $68.5 \%$ & $0.6 \%$ & $4.1 \%$ \\
\hline butan-1-ol & $18.2 \%$ & $72.8 \%$ & $1.1 \%$ & $7.8 \%$ \\
\hline hexan-1-ol & $28.5 \%$ & $61.9 \%$ & $1.2 \%$ & $8.4 \%$ \\
\hline 2-phenylethanol & $1.3 \%$ & $28.0 \%$ & $23.2 \%$ & $47.4 \%$ \\
\hline (Z)-hex-3-en-1-ol* & $8.0 \%$ & $45.8 \%$ & $5.9 \%$ & $40.3 \%$ \\
\hline pentan-1-ol* & $18.3 \%$ & $55.2 \%$ & $3.6 \%$ & $23.0 \%$ \\
\hline prop-2-en-1-ol & $8.5 \%$ & $68.8 \%$ & $11.8 \%$ & $10.9 \%$ \\
\hline \multicolumn{5}{|c|}{ Esters } \\
\hline ethyl acetate & $63.8 \%$ & $30.3 \%$ & $0.8 \%$ & $5.2 \%$ \\
\hline 3-methylbutyl acetate & $72.8 \%$ & $13.4 \%$ & $2.9 \%$ & $10.9 \%$ \\
\hline ethyl 2-hydroxypropanoate & $2.9 \%$ & $41.9 \%$ & $22.4 \%$ & $32.8 \%$ \\
\hline ethyl octanoate* & $51.4 \%$ & $28.4 \%$ & $9.2 \%$ & $10.9 \%$ \\
\hline ethyl decanoate & $66.2 \%$ & $4.1 \%$ & $3.8 \%$ & $25.8 \%$ \\
\hline diethyl butanedioate & $3.6 \%$ & $53.7 \%$ & $23.7 \%$ & $19.1 \%$ \\
\hline 2-phenylethyl acetate* & $22.3 \%$ & $32.2 \%$ & $11.1 \%$ & $34.4 \%$ \\
\hline ethyl 3-hydroxybutanoate* & $8.9 \%$ & $39.5 \%$ & $10.9 \%$ & $40.7 \%$ \\
\hline ethyl propanoate & $86.5 \%$ & $9.2 \%$ & $3.5 \%$ & $0.8 \%$ \\
\hline \multicolumn{5}{|c|}{ Aldehydes } \\
\hline Acetaldehyde* & $20.6 \%$ & $38.0 \%$ & $8.0 \%$ & $33.3 \%$ \\
\hline 1,1-diethoxyethane* & $43.2 \%$ & $33.3 \%$ & $3.0 \%$ & $20.5 \%$ \\
\hline 2-methylpropanal* & $23.3 \%$ & $34.1 \%$ & $12.2 \%$ & $30.4 \%$ \\
\hline \multicolumn{5}{|c|}{ Phenols } \\
\hline 4-ethylcatechol & $0.7 \%$ & $0.3 \%$ & $0.2 \%$ & $98.8 \%$ \\
\hline 4-ethylphenol & $2.2 \%$ & $38.0 \%$ & $25.6 \%$ & $34.2 \%$ \\
\hline 4-ethylguaiacol & $4.9 \%$ & $68.6 \%$ & $22.8 \%$ & $3.7 \%$ \\
\hline 4-vinylanisol* & $23.6 \%$ & $37.4 \%$ & $5.3 \%$ & $33.8 \%$ \\
\hline
\end{tabular}

* compounds with mass balance higher than $\pm 25 \%$ 
Table 7 Compounds distribution during the second brouillis distillation (BD2).

\begin{tabular}{|c|c|c|c|c|c|}
\hline $\begin{array}{l}\% \text { Exit } \\
\Sigma(\mathrm{Hd}+\mathrm{Ht}+\mathrm{S}+\mathrm{T}+\mathrm{Dv}+\mathrm{R})\end{array}$ & $\mathrm{Hd}_{\mathrm{BD} 2}$ & $\mathrm{Ht}_{\mathrm{BD} 2}$ & $\mathrm{~S}_{\mathrm{BD} 2}$ & $\mathrm{~T}_{\mathrm{BD} 2}$ & $(\mathrm{Dv}+\mathrm{R})_{\mathrm{BD} 2}$ \\
\hline ethanol & $4.6 \%$ & $78.9 \%$ & $15.1 \%$ & $1.3 \%$ & $0.1 \%$ \\
\hline \multicolumn{6}{|c|}{ Alcohols } \\
\hline methanol & $4.0 \%$ & $70.6 \%$ & $20.6 \%$ & $3.5 \%$ & $1.4 \%$ \\
\hline propan-1-ol & $4.7 \%$ & $84.6 \%$ & $10.1 \%$ & $0.2 \%$ & $0.3 \%$ \\
\hline 2-methylpropan-1-ol & $6.3 \%$ & $89.2 \%$ & $2.4 \%$ & $0.3 \%$ & $1.9 \%$ \\
\hline 2-methylbutan-1-ol & $5.2 \%$ & $92.2 \%$ & $2.2 \%$ & $0.0 \%$ & $0.3 \%$ \\
\hline 3-methylbutan-1-ol & $4.4 \%$ & $90.8 \%$ & $3.4 \%$ & $0.2 \%$ & $1.1 \%$ \\
\hline butan-2-ol & $7.2 \%$ & $90.0 \%$ & $1.9 \%$ & $0.1 \%$ & $0.7 \%$ \\
\hline butan-1-ol & $4.2 \%$ & $86.8 \%$ & $7.6 \%$ & $0.2 \%$ & $1.2 \%$ \\
\hline hexan-1-ol & $3.2 \%$ & $91.6 \%$ & $3.4 \%$ & $0.3 \%$ & $1.6 \%$ \\
\hline 2-phenylethanol & $0.1 \%$ & $9.9 \%$ & $23.3 \%$ & $15.2 \%$ & $51.5 \%$ \\
\hline (Z)-hex-3-en-1-ol & $0.9 \%$ & $71.6 \%$ & $18.0 \%$ & $1.3 \%$ & $8.2 \%$ \\
\hline pentan-1-ol & $4.4 \%$ & $83.7 \%$ & $6.3 \%$ & $0.8 \%$ & $4.8 \%$ \\
\hline prop-2-en-1-ol & $3.3 \%$ & $69.6 \%$ & $22.2 \%$ & $3.0 \%$ & $1.9 \%$ \\
\hline \multicolumn{6}{|c|}{ Esters } \\
\hline ethyl acetate & $27.2 \%$ & $69.6 \%$ & $0.9 \%$ & $0.3 \%$ & $2.0 \%$ \\
\hline 3-methylbutyl acetate* & $17.1 \%$ & $61.1 \%$ & $3.3 \%$ & $2.5 \%$ & $16.1 \%$ \\
\hline ethyl 2-hydroxypropanoate & $0.6 \%$ & $29.3 \%$ & $34.1 \%$ & $12.3 \%$ & $23.7 \%$ \\
\hline ethyl octanoate & $2.2 \%$ & $43.0 \%$ & $42.2 \%$ & $8.4 \%$ & $4.1 \%$ \\
\hline ethyl decanoate* & $12.4 \%$ & $46.2 \%$ & $11.4 \%$ & $4.1 \%$ & $25.9 \%$ \\
\hline diethyl butanedioate & $0.4 \%$ & $30.1 \%$ & $47.2 \%$ & $11.5 \%$ & $10.9 \%$ \\
\hline 2-phenylethyl acetate* & $0.8 \%$ & $7.9 \%$ & $7.3 \%$ & $1.3 \%$ & $82.7 \%$ \\
\hline ethyl 3-hydroxybutanoate* & $1.4 \%$ & $39.2 \%$ & $12.3 \%$ & $3.8 \%$ & $43.3 \%$ \\
\hline ethyl propanoate* & $64.1 \%$ & $21.0 \%$ & $3.4 \%$ & $3.2 \%$ & $8.3 \%$ \\
\hline \multicolumn{6}{|c|}{ Aldehydes } \\
\hline acetaldehyde & $27.9 \%$ & $58.5 \%$ & $2.1 \%$ & $1.6 \%$ & $10.0 \%$ \\
\hline 1,1-diethoxyethane* & $15.7 \%$ & $80.8 \%$ & $0.5 \%$ & $0.4 \%$ & $2.6 \%$ \\
\hline 2-methylpropanal & $50.2 \%$ & $28.5 \%$ & $3.3 \%$ & $2.4 \%$ & $15.5 \%$ \\
\hline \multicolumn{6}{|c|}{ Phenols } \\
\hline 4-ethylcatechol & $24.7 \%$ & $57.8 \%$ & $1.0 \%$ & $0.5 \%$ & $15.9 \%$ \\
\hline 4-ethylphenol & $0.1 \%$ & $15.3 \%$ & $37.0 \%$ & $21.8 \%$ & $25.8 \%$ \\
\hline 4-ethylguaiacol & $0.3 \%$ & $31.4 \%$ & $49.4 \%$ & $14.4 \%$ & $4.6 \%$ \\
\hline 4-vinylanisol & $2.6 \%$ & $73.5 \%$ & $15.0 \%$ & $1.8 \%$ & $7.2 \%$ \\
\hline
\end{tabular}

* compounds with mass balance higher than $\pm 25 \%$ 
Table 8 Comparison of volatile compound concentrations in $\mathrm{g} / \mathrm{hL}$ PA of starting cider, mean value of boiler of cider distillations, mean value of brouillis produced, hearts of brouillis distillations, and ratio of heart form the second brouillis distillation $\left(\mathrm{Ht}_{\mathrm{BD} 2}\right)$ to cider.

\begin{tabular}{|c|c|c|c|c|c|c|}
\hline & Cider & $\begin{array}{c}\text { Boiler } \\
\text { mean } \\
\text { value }\end{array}$ & $\begin{array}{r}\text { Brouillis } \\
\text { mean } \\
\text { value }\end{array}$ & $\mathrm{Ht}_{\mathrm{BD} 1}$ & $\mathrm{Ht}_{\mathrm{BD} 2}$ & $\frac{\mathrm{Ht}_{\mathrm{BD} 2}}{\text { cider }}$ \\
\hline $\mathrm{ABV}(\% \mathrm{v} / \mathrm{v})$ & 7.00 & 7.24 & 32.56 & 72.20 & 72.20 & \\
\hline \multicolumn{7}{|l|}{ Alcohols (g/hL PA) } \\
\hline methanol & 68.10 & 77.27 & 65.77 & 55.03 & 60.56 & $88.9 \%$ \\
\hline propan-1-ol & 366.27 & 372.88 & 368.33 & 419.78 & 386.84 & $105.6 \%$ \\
\hline 2-methylpropan-1-ol & 38.45 & 41.58 & 39.49 & 47.54 & 38.96 & $101.3 \%$ \\
\hline 2-methylbutan-1-ol & 39.23 & 43.20 & 39.84 & 48.27 & 40.00 & $102.0 \%$ \\
\hline 3-methylbutan-1-ol & 132.05 & 142.18 & 138.85 & 168.43 & 141.11 & $106.9 \%$ \\
\hline butan-2-ol & 90.81 & 98.74 & 95.55 & 115.29 & 94.00 & $103.5 \%$ \\
\hline butan-1-ol & 5.92 & 5.89 & 5.94 & 6.76 & 6.02 & $101.8 \%$ \\
\hline hexan-1-ol & 3.78 & 4.06 & 3.66 & 4.36 & 3.70 & $97.7 \%$ \\
\hline 2-phenylethanol & 64.12 & 74.94 & 28.81 & 2.81 & 3.47 & $5.4 \%$ \\
\hline (Z)-hex-3-en-1-ol* & 0.25 & 0.26 & 0.25 & 0.21 & 0.26 & $100.8 \%$ \\
\hline pentan-1-ol* & 0.13 & 0.26 & 0.25 & 0.29 & 0.24 & $191.0 \%$ \\
\hline prop-2-en-1-ol & 6.69 & 7.57 & 6.91 & 5.74 & 6.51 & $97.2 \%$ \\
\hline \multicolumn{7}{|l|}{ Esters $(g / h L P A)$} \\
\hline ethyl acetate & 202.02 & 308.60 & 134.01 & 115.85 & 106.02 & $52.5 \%$ \\
\hline 3-methylbutyl acetate* & 0.52 & 1.65 & 0.31 & 0.26 & 0.24 & $45.1 \%$ \\
\hline ethyl 2-hydroxypropanoate & 312.88 & 370.65 & 169.12 & 48.91 & 64.64 & $20.7 \%$ \\
\hline ethyl octanoate* & 3.36 & 4.06 & 0.86 & 0.40 & 0.52 & $15.5 \%$ \\
\hline ethyl decanoate* & 0.52 & 0.55 & 0.04 & 0.11 & 0.05 & $10.0 \%$ \\
\hline diethyl butanedioate & 7.57 & 8.74 & 5.14 & 1.48 & 2.31 & $30.5 \%$ \\
\hline 2-phenylethyl acetate* & 0.32 & 0.32 & 0.04 & 0.02 & 0.02 & $5.9 \%$ \\
\hline ethyl 3-hydroxybutanoate* & 0.17 & 0.36 & 0.31 & 0.25 & 0.21 & $124.5 \%$ \\
\hline ethyl propanoate* & 12.98 & 21.60 & 1.81 & 0.67 & 0.64 & $4.9 \%$ \\
\hline \multicolumn{7}{|l|}{ Aldehydes ( $g / h L P A)$} \\
\hline Acetaldehyde* & 4.59 & 5.49 & 5.87 & 3.69 & 3.16 & $69.0 \%$ \\
\hline 1,1-diethoxyethane $*$ & 2.56 & 2.67 & 2.67 & 5.41 & 4.51 & $176.6 \%$ \\
\hline 2-methylpropanal* & 0.20 & 0.22 & 0.20 & 0.11 & 0.04 & $21.6 \%$ \\
\hline \multicolumn{7}{|l|}{ Phenols (g/hL PA) } \\
\hline 4-ethylcatechol & 34.13 & 27.11 & 0.09 & 0.05 & 0.05 & $0.2 \%$ \\
\hline 4-ethylphenol & 4.09 & 4.67 & 2.28 & 0.35 & 0.52 & $12.7 \%$ \\
\hline 4-ethylguaiacol & 0.86 & 0.92 & 0.65 & 0.20 & 0.33 & $38.7 \%$ \\
\hline 4-vinylanisol* & $4 E-03$ & $4 E-03$ & $4 E-03$ & $3 E-03$ & $3 E-03$ & $74.9 \%$ \\
\hline
\end{tabular}

* compounds with one mass balance higher than $\pm 25 \%$ 
Table 9 :Odorant quality, threshold in $46 \% \mathrm{v} / \mathrm{v}$ solution and OAV estimation of heart $\left(\mathrm{Ht}_{\mathrm{BD} 2}\right)$

\begin{tabular}{|c|c|c|c|c|c|}
\hline Key odorant in bold ${ }^{\mathrm{a}}$ & Odour quality & $\begin{array}{l}\text { Odorant } \\
\text { threshold } \\
(\mu \mathrm{g} / \mathrm{L}) \\
\text { at } 46 \% \mathrm{v} / \mathrm{v}\end{array}$ & $\begin{array}{l}\mathrm{Ht}_{\mathrm{BD} 2} \\
(\mathrm{mg} / \mathrm{L}) \\
\text { at } 72.2 \% \mathrm{v} / \mathrm{v}\end{array}$ & $\begin{array}{l}\mathrm{Ht}_{\mathrm{BD} 2} \\
(\mu \mathrm{g} / \mathrm{L}) \\
\text { at } 46 \% \mathrm{v} / \mathrm{v}\end{array}$ & $O A V^{f}$ \\
\hline \multicolumn{6}{|l|}{ Alcohols } \\
\hline methanol & & & 437.24 & 278571 & \\
\hline propan-1-ol & fruity $^{\mathrm{b}}$, alcoholic ${ }^{\mathrm{b}, \mathrm{c}}$ & $54000^{\mathrm{b}}$ & 2792.97 & 1779455 & 32.9 \\
\hline 2-methylpropan-1-ol & wine $^{\mathrm{b}}$, malty $^{\mathrm{c}}$, etheral ${ }^{\mathrm{d}}$ & $28300^{c}$ & 281.31 & 179229 & 6.3 \\
\hline 2-methylbutan-1-ol & roasted $^{\mathrm{d}}$ & & 288.83 & 184020 & \\
\hline 3-methylbutan-1-ol & fruity $^{\mathrm{b}}$, nail polish ${ }^{\mathrm{b}}$ malty $^{\mathrm{c}}$ & $179000^{c}$ & 1018.82 & 649108 & 3.6 \\
\hline butan-2-ol & fruity & $50000^{\mathrm{b}}$ & 678.68 & 432398 & 8.6 \\
\hline butan-1-ol & fruity $^{\mathrm{b}}$, alcoholic $^{\mathrm{c}}$, solvent ${ }^{\mathrm{c}}$ & $2730^{c}$ & 43.50 & 27714 & 10.1 \\
\hline hexan-1-ol & floral $^{\mathrm{b}}$, green $^{\mathrm{b}}$ & $5370^{\mathrm{c}}$ & 26.70 & 17010 & 3.2 \\
\hline 2-phenylethanol & rosy $^{\mathrm{c}}$, honey $^{\mathrm{c}}$ & $28900^{c}$ & 25.09 & 15983 & 0.5 \\
\hline (Z)-hex-3-en-1-ol* & grass $^{e}$, green $^{e}$ & & 1.85 & 1178 & \\
\hline pentan-1-ol* & fruity $^{b}$, balsamic $^{c}$ & $37400^{b}$ & 1.75 & 1116 & 0.03 \\
\hline prop-2-en-1-ol & fruity $^{\mathrm{b}, \mathrm{c}}$, alcoholic ${ }^{\mathrm{e}}$ & $1100^{\mathrm{b}}$ & 46.99 & 29941 & 27.2 \\
\hline \multicolumn{6}{|l|}{ Esters } \\
\hline ethyl acetate & pineapple $e^{b, c}$ & $32600^{c}$ & 765.49 & 487708 & 15.0 \\
\hline 3-methylbutyl acetate* & fruity $^{c, e}$, sweet $^{e}$ & $93.9^{c}$ & 1.70 & 1083 & 11.5 \\
\hline ethyl 2-hydroxypropanoate & fruity $^{c}$ & $128000^{c}$ & 466.69 & 297337 & 2.3 \\
\hline ethyl octanoate* & fruity $^{c, e}$, sweet $^{e}$ & $12.9^{c}$ & 3.76 & 2395 & 185.7 \\
\hline ethyl decanoate* & fruity $^{c}$ & $1120^{c}$ & 0.38 & 241 & 0.2 \\
\hline diethyl butanedioate & fruity ${ }^{\mathrm{c}}$ & $353000^{\mathrm{c}}$ & 16.65 & 10609 & 0.03 \\
\hline 2-phenylethyl acetate & floral $^{c}$ & $909^{c}$ & 0.14 & 87 & 0.10 \\
\hline ethyl 3-hydroxybutanoate* & fruity $^{d}$ & & 1.52 & 971 & \\
\hline ethyl propanoate* & banana $^{c}$ & $19000^{c}$ & 4.61 & 2934 & 0.15 \\
\hline \multicolumn{6}{|l|}{ Aldehydes } \\
\hline acetaldehyde* & ethereal $^{d}$ & $1200^{b}$ & 22.85 & 14558 & 12.1 \\
\hline 1,1-diethoxyethane* & fruity $^{c}$, ethereal ${ }^{d}$ & $2090^{c}$ & 32.58 & 20757 & 9.9 \\
\hline 2-methylpropanal* & aldehydic $^{d}$ & $1300^{b}$ & 0.31 & 196 & 0.15 \\
\hline \multicolumn{6}{|l|}{ Phenols } \\
\hline 4-ethylcatechol & & & 0.40 & 252 & \\
\hline 4-ethylphenol & smoky ${ }^{\mathrm{d}}$ & $123^{\mathrm{a}}$ & 3.75 & 2390 & 19.4 \\
\hline 4-ethylguaiacol & glove $^{\mathrm{c}}$, spicy ${ }^{\mathrm{d}}$ & $123^{c}$ & 2.40 & 1532 & 12.5 \\
\hline 4-vinylanisol* & sweet $^{d}$ & & 0.02 & 15 & \\
\hline
\end{tabular}

*Compounds with a balance higher than $\pm 25 \%$

a Key odorants according to Zhao et al. (2014),

bWang et al. (2014).

${ }^{\mathrm{c}} \mathrm{Gao}$ et al. (2014).

${ }^{\mathrm{d}}$ The good scents.

'Xiang et al. (2020).

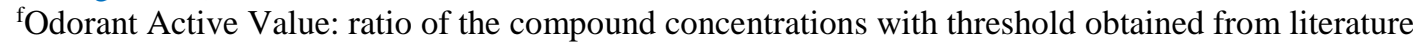




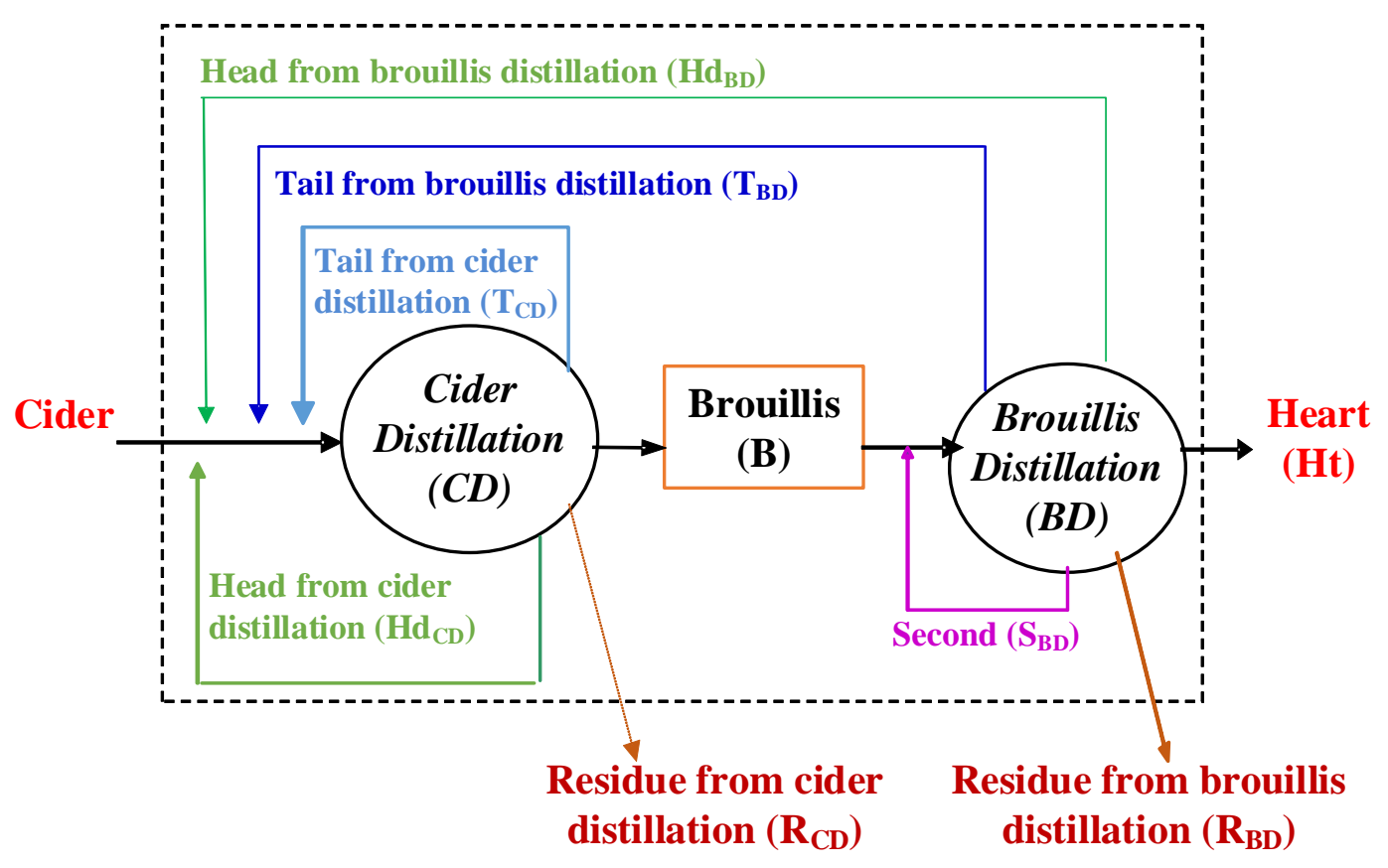

Fig. 1. Diagram of the production of Calvados by discontinuous double distillation 

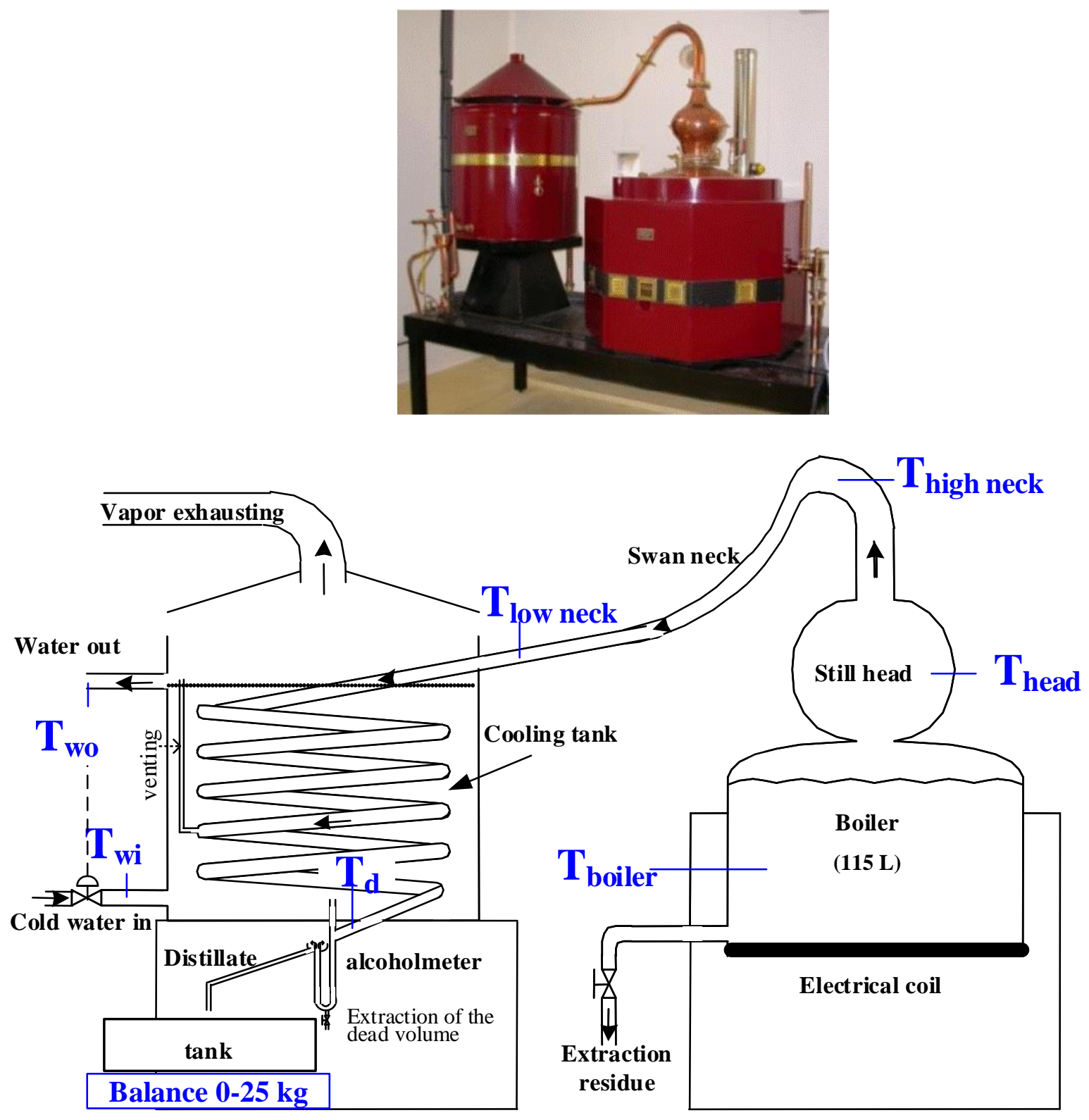

Fig. 2. Photo and scheme of the $115 \mathrm{~L}$ pilot still used 


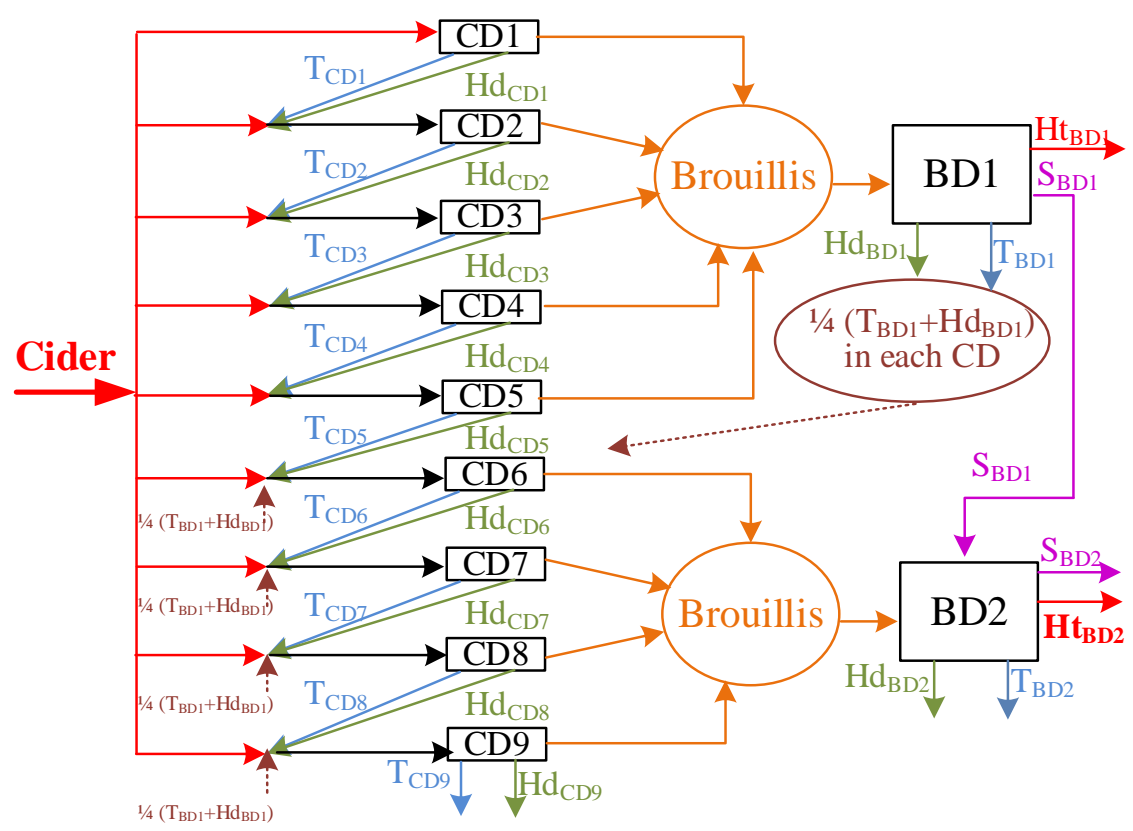

Fig. 3. Organization of cider and brouillis distillations 

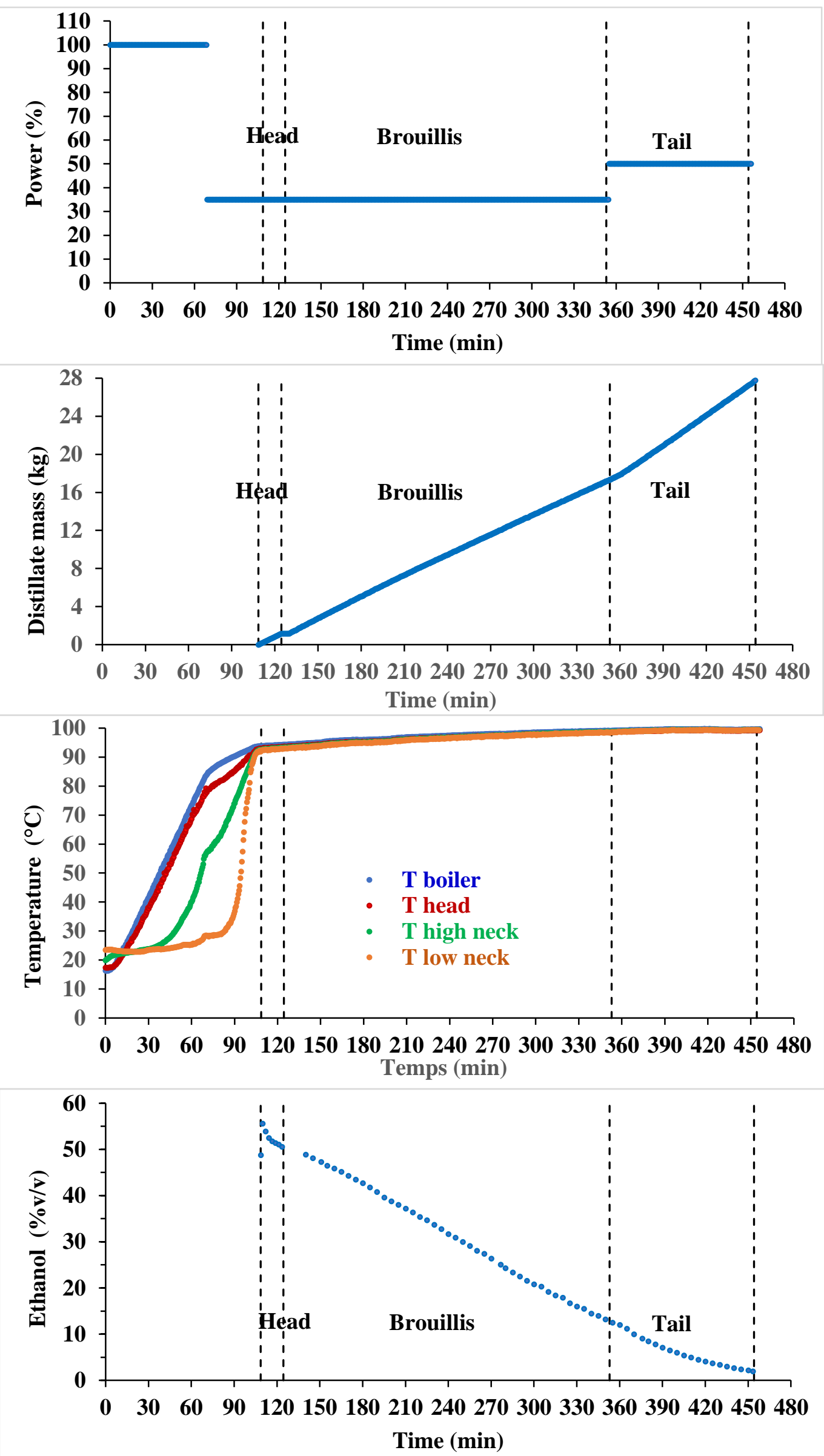

Fig. 4. Example of parameters evolution during cider distillation (CD2) 

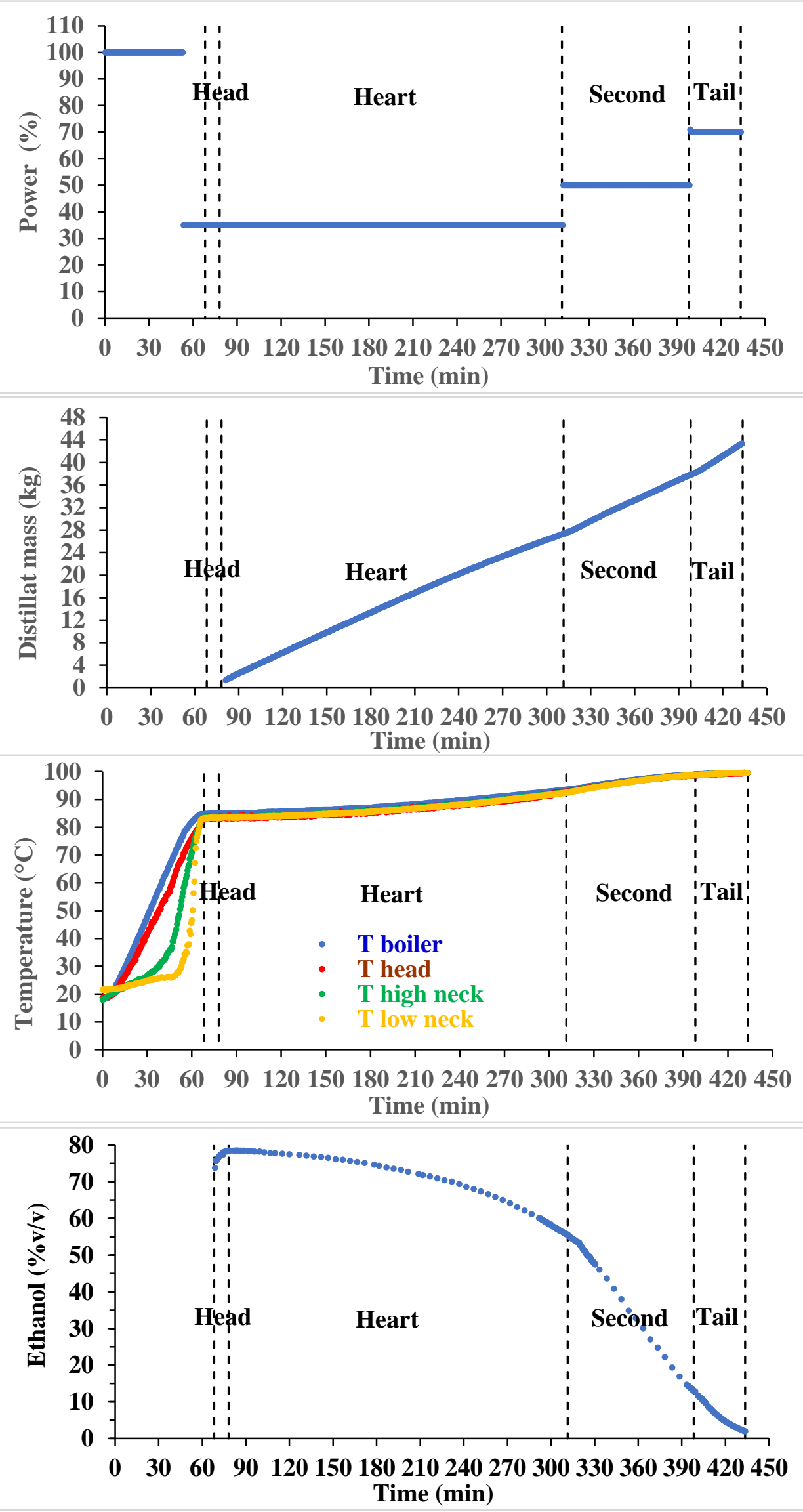

Fig. 5. Example of parameters evolution during brouillis distillation (BD2) 

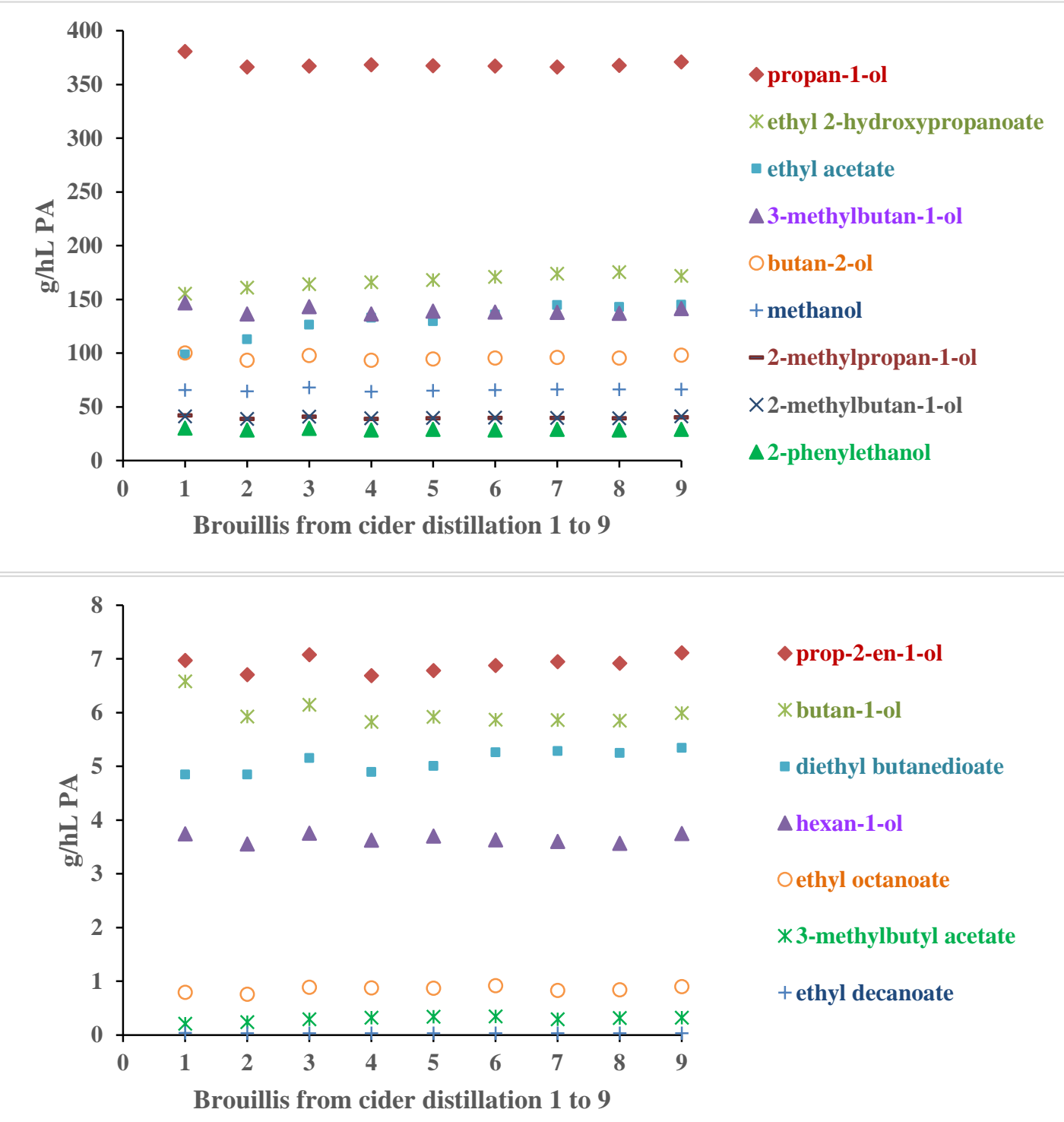

Fig. 6. Evolution of major compounds' concentration into the brouillis from cider distillations 1 to 9 

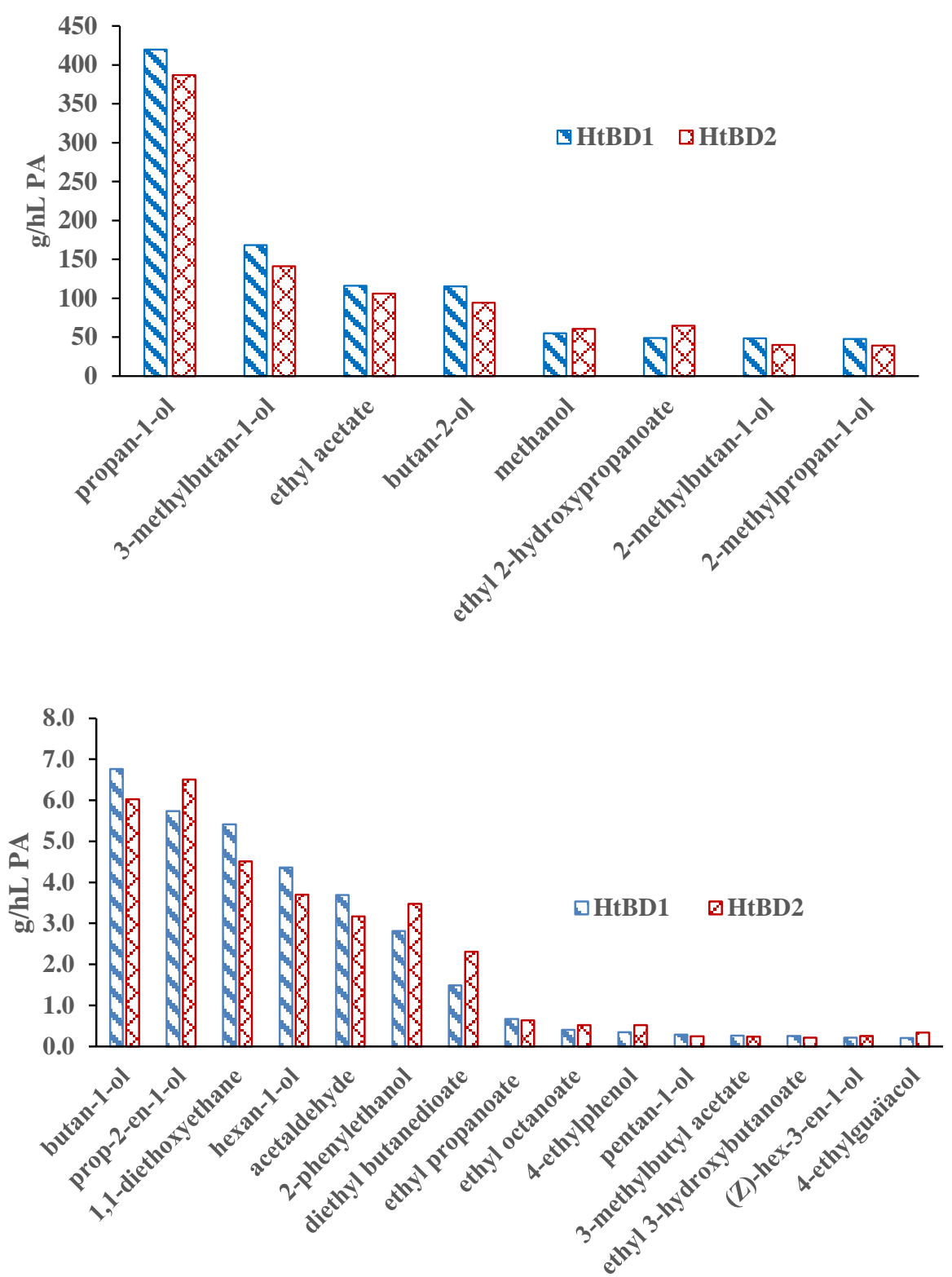

Fig. 7. Evolution of the major compounds' concentration into the two hearts 